\title{
The CACNA1F Gene Encodes an L-Type Calcium Channel with Unique Biophysical Properties and Tissue Distribution
}

\author{
John E. McRory, ${ }^{1}$ Jawed Hamid, ${ }^{2}$ Clinton J. Doering, ${ }^{2,3}$ Esperanza Garcia, ${ }^{1}$ Robin Parker, ${ }^{4}$ Kevin Hamming, ${ }^{1}$ Lina Chen, ${ }^{2}$ \\ Michael Hildebrand, ${ }^{1}$ Aaron M. Beedle, ${ }^{2}$ Laura Feldcamp, ${ }^{2}$ Gerald W. Zamponi, ${ }^{2}$ and Terrance P. Snutch ${ }^{1}$ \\ ${ }^{1}$ Biotechnology Laboratory, University of British Columbia, Vancouver, British Columbia, Canada V6T 1Z3, ${ }^{2}$ Department of Physiology and Biophysics, \\ Cellular and Molecular Neurobiology Research Group, University of Calgary, Calgary, Alberta, Canada T2N 4N1, ${ }^{3}$ NeuroMed Technologies Inc., Vancouver, \\ British Columbia, Canada V6T 1Z4, and ${ }^{4}$ Department of Pathology, Vancouver General Hospital, Vancouver, British Columbia, Canada V5Z 1M9
}

Glutamate release from rod photoreceptors is dependent on a sustained calcium influx through L-type calcium channels. Missense mutations in the CACNA1F gene in patients with incomplete $\mathrm{X}$-linked congenital stationary night blindness implicate the $\mathrm{Ca}_{\mathrm{v}} 1.4$ calcium channel subtype. Here, we describe the functional and pharmacological properties of transiently expressed human $\mathrm{Ca}_{\mathrm{v}} 1.4$ calcium channels. $\mathrm{Ca}_{\mathrm{v}} 1.4$ is shown to encode a dihydropyridine-sensitive calcium channel with unusually slow inactivation kinetics that are not affected by either calcium ions or by coexpression of ancillary calcium channel $\beta$ subunits. Additionally, the channel supports a large window current and activates near $-40 \mathrm{mV}$ in $2 \mathrm{~mm}$ external calcium, making $\mathrm{Ca}_{\mathrm{v}} 1.4$ ideally suited for tonic calcium influx at typical photoreceptor resting potentials. Introduction of base pair changes associated with four incomplete $\mathrm{X}$-linked congenital night blindness mutations showed that only the G369D alteration affected channel activation properties. Immunohistochemical analyses show that, in contrast with previous reports, $\mathrm{Ca}_{\mathrm{v}} 1.4$ is widely distributed outside the retina, including in the immune system, thus suggesting a broader role in human physiology.

Key words: calcium channel; retina; night blindness; channelopathies; mast cells; plasma cells

\section{Introduction}

Neurotransmitter release is critically dependent on calcium entry through voltage-gated calcium channels. In most central and peripheral nerve synapses, the release process is triggered by the transient activation and opening of $\mathrm{N}$-type and P/Q-type calcium channels in response to membrane depolarizations arising from action potentials arriving at the presynaptic nerve terminal (Wheeler et al., 1994). This contrasts with synaptic transmission in photoreceptor cells that operate via graded changes in membrane potential (Knapp and Dowling, 1987), where these cells are depolarized in the absence of light stimuli and tonically secrete neurotransmitter triggered by calcium entry predominantly through L-type calcium channels (Schneeweis and Schapf, 1995; Nachman-Clewner et al., 1999). Light stimuli hyperpolarize the

\footnotetext{
Received 0ct. 28, 2003; revised Dec. 1, 2003; accepted Dec. 2, 2003.

This work was supported by operating grants from the Canadian Institutes for Health Research (CIHR) to T.P.S. and G.W.Z. T.P.S. is a CIHR Senior Investigator. G.W.Z. is a CIHR Investigator, a Senior Scholar of the Alberta Heritage Foundation for Medical Research (AHFMR), and a National Alliance for Research on Schizophrenia and Depression Independent Investigator. J.E.M. was supported by a CIHR Postdoctoral Fellowship Award, M.H. by a Natural Sciences and Engineering Research Council (Canada) graduate studentship, and A.B. and C.J.D. hold AHFMR studentships.

Correspondence should be addressed to Dr. Terrance P. Snutch, Biotechnology Laboratory, University of British Columbia, 6174 University Boulevard, Vancouver, British Columbia, Canada V6T 1Z3. E-mail: Snutch@zoology.ubc.ca.

J. E. McRory's present address: Department of Physiology and Biophysics, Cellular and Molecular Neurobiology Research Group, University of Calgary, Calgary, Alberta, Canada T2N 4N1.

E. Garcia's present address: Centro de Investigaciones Biomedicas, Universidad de Colima, A.P. 199, Colima, 2800, Mexico.

DOI:10.1523/JNEUROSCI.4846-03.2004

Copyright $\odot 2004$ Society for Neuroscience $\quad 0270-6474 / 04 / 241707-12 \$ 15.00 / 0$
}

photoreceptor cell and, thus, terminate calcium entry via L-type channels. Molecular cloning has led to the definitive identification of four genes encoding distinct L-type calcium channels. $\mathrm{Ca}_{\mathrm{v}} 1.1\left(\alpha_{1 \mathrm{~S}}\right)$ L-type channels are found exclusively in skeletal muscle and serve predominantly as a voltage sensor for excitation contraction coupling (Beam et al., 1992). In contrast, $\mathrm{Ca}_{\mathrm{v}} 1.2$ $\left(\alpha_{1 \mathrm{C}}\right)$ and $\mathrm{Ca}_{\mathrm{v}} 1.3\left(\alpha_{1 \mathrm{D}}\right)$ L-type calcium channels are expressed in a variety of tissues, including most neurons, smooth and cardiac muscle, and endocrine cells (Seino et al., 1992; Williams et al., 1992a; Hell et al., 1993). The $\mathrm{Ca}_{\mathrm{v}} 1.2$ and $\mathrm{Ca}_{\mathrm{v}} 1.3$ channels can be distinguished based on their distinct pharmacological properties, with $\mathrm{Ca}_{\mathrm{v}} 1.3$ channels exhibiting both a reduced sensitivity to dihydropyridine (DHP) antagonists (Koschak et al., 2001; Xu and Lipscombe, 2001) and a moderate sensitivity to the N-type calcium channel blocker $\omega$-conotoxin GVIA (Williams et al., 1992b). More recently, the CACNA1F ( $\left.\mathrm{Ca}_{\mathrm{v}} 1.4\right)$ gene in humans has been identified as being associated with patients with incomplete X-linked congenital stationary night blindness (CSNB2) (Bech-Hansen et al.,1998a,b; Strom et al., 1998), although little is known about the detailed biophysical and pharmacological properties of $\mathrm{Ca}_{\mathrm{v}} 1.4$ channels. Moreover, the consequence of missense mutations linked to CSNB2 on channel function remains to be described.

Salamander rod and cone photoreceptor L-type calcium channels (Corey et al., 1984; Wilkinson and Barnes 1996; Kourennyi and Barnes, 2000), as well as L-type calcium channels expressed in mammalian Muller and photoreceptor cells (Yagi and Macleish, 1994; Puro et al., 1996; de la Villa et al., 1998; Protti 
and Llano, 1998; Taylor and Morgans, 1998; Berntson et al., 2003), exhibit similar biophysical properties, including relatively slow kinetics, a low affinity for DHP antagonists, as well as a weak sensitivity to $\omega$-conotoxin GVIA. Although these properties are primarily consistent with $\mathrm{Ca}_{\mathrm{v}} 1.3$ channels comprising at least part of L-type currents in photoreceptors, the observation that $\mathrm{Ca}_{\mathrm{v}} 1.3$ antibodies do not label rod photoreceptors suggests that they express a distinct L-type channel isoform (Taylor and Morgans, 1998; Morgans, 1999). Considering that impairment of vision in CSNB2 patients is linked to mutations in $\mathrm{Ca}_{\mathrm{v}} 1.4$ channels, the evidence suggests that rods may rely predominantly on $\mathrm{Ca}_{\mathrm{v}} 1.4$ for signal transduction.

We report the functional characterization of $\mathrm{Ca}_{\mathrm{v}} 1.4$ calcium channels as well as the analysis of four mutations associated with CSNB2. Functional expression of the $\mathrm{Ca}_{\mathrm{v}} 1.4$ calcium channel in human embryonic kidney (HEK) tsA-201 cells reveals that $\mathrm{Ca}_{\mathrm{v}} 1.4$ encodes a DHP-sensitive calcium channel that preferentially conducts barium over calcium but, unlike other high-voltageactivated calcium channels (Liang et al., 2003), shows no discernable calcium-dependent inactivation. The $\mathrm{Ca}_{\mathrm{v}} 1.4$ channels first activate at relatively negative potentials and, unlike other highthreshold calcium channels, display unusually slow voltagedependent inactivation characteristics irrespective of the type of calcium channel $\beta$ subunit coexpressed. This, together with the occurrence of a large window current, makes $\mathrm{Ca}_{\mathrm{v}} 1.4$ channels ideally suited for maintaining tonic release at photoreceptor synapses. Immunohistochemical localization of $\mathrm{Ca}_{\mathrm{v}} 1.4$ reveals that, in contrast with previous reports (Bech-Hansen et al. 1998a,b), $\mathrm{Ca}_{\mathrm{v}} 1.4$ expression is not only confined to the retina but is also detected at significant levels in the adrenal gland, bone marrow, spinal cord, muscle, and spleen. Moreover, $\mathrm{Ca}_{\mathrm{v}} 1.4$ appears to be present at high levels in plasma cells and mast cells, suggesting a potential role of $\mathrm{Ca}_{\mathrm{v}} 1.4$ in mediating immune responses.

\section{Materials and Methods}

Cloning of the human $\mathrm{Ca}_{v} 1.4$ calcium channel. To isolate the full-length cDNA, we used the nucleotides from exons 47 and 48 of the human gene sequence to identify two expressed sequence tags (ESTs) (GenBank accession numbers AA317815 and AA019975) from the National Center for Biotechnology Information database. These ESTs were then used to screen a human retinal cDNA library (a generous gift from Dr. Jeremy Nathans, Johns Hopkins University, Baltimore, MD). Screening of 200,000 pfu from the library resulted in isolation of two clones that encoded for nucleotides $2864-5871$ of the channel (nucleotides numbered as to GenBank accession number NM_005183). To isolate the remainder of the clones (clones 1 and 2), oligonucleotides were made to the deduced cDNA sequence, and PCR was used to amplify and clone the remainder of the $\mathrm{Ca}_{\mathrm{v}} 1.4$ full-length $\mathrm{cDNA}$. Oligonucleotides used to amplify the remaining regions were synthesized to regions corresponding to nucleotides 1-19, 1653-1672, 1541-1559, and 3221-3239. PCR reaction conditions consisted of a $50 \mu \mathrm{l}$ reaction with $10 \times$ PCR buffer, 20 pmol of each oligonucleotide, $10 \mathrm{~mm}$ dNTP, $2.5 \mathrm{U}$ of HotStart TaqDNA polymerase (Qiagen, Hilden, Germany), and $1 \mu \mathrm{l}$ of retinal library heated for $94^{\circ} \mathrm{C}(15 \mathrm{~min})$, followed by 35 cycles at $95^{\circ} \mathrm{C}(30 \mathrm{sec}), 55^{\circ} \mathrm{C}(1 \mathrm{~min})$, and $74^{\circ} \mathrm{C}$ ( $\left.2 \mathrm{~min}\right)$. To confirm the cDNA sequences, all PCR products and isolated library clones were sequenced. Sequencing oligonucleotides corresponded to nucleotides 721-728, 1389-1406, 2152-2169, 3005-3021, 3695-3712, 4432-4450, and 5265-5282 (GenBank accession number NM_005183). The 5' end PCR products were ligated together using the unique NarI and ClaI sites, and the full-length clone was then assembled in pBluescript KS using the isolated cDNA library cDNA clone and ClaI and $\mathrm{XbaI}$. For expression studies, the $\mathrm{Ca}_{\mathrm{v}} 1.4 \mathrm{cDNA}$ clone was transferred to pcDNA3-ZEO using SalI and XbaI, and the DNA sequence was again confirmed. Full-length cDNA clones that contained the reported CSNB2 mutations were synthesized using the Quick-Change Site-Directed Mu- tagenesis kit according to the manufacturer's instructions, and all mutated DNA sequences were confirmed via direct DNA sequencing.

Transient expression of the $C a_{v} 1.4 c D N A$ clone. Cells used for transient transfection (tsA-201) were maintained in standard DMEM supplemented with $10 \% \mathrm{FBS}$ and $50 \mathrm{U} / \mathrm{ml}$ penicillin-streptomycin to $80 \%$ confluence. Cells were maintained at $37^{\circ} \mathrm{C}$ in a humidified environment of $5 \% \mathrm{CO}_{2}$ and every $2-3 \mathrm{~d}$ were dissociated enzymatically with trypsinEDTA and plated on $15 \mathrm{~mm}$ coverslips in $110 \mathrm{~mm}$ dishes. A standard calcium phosphate procedure was used to transiently transfect the cells. The human $\mathrm{Ca}_{\mathrm{v}} 1.4 \mathrm{cDNA}$ clone $(6 \mu \mathrm{g})$ was cotransfected with one of the rat $\beta$ subunits $(6 \mu \mathrm{g})$ (i.e., $\beta_{2 \mathrm{a}}, \beta_{1 \mathrm{~b}}, \beta_{3}$, or $\left.\beta_{4}\right)$ and the rat $\alpha_{2}-\delta_{1}(6 \mu \mathrm{g}$ ) subunit. In addition, we cotransfected pIRES-enhanced green fluorescent protein (EGFP) (1 $\mu \mathrm{g}$; Clontech, Cambridge, UK) as a marker plasmid. Transfected cells were incubated in the media overnight, then the media was exchanged and the plates were incubated at $29^{\circ} \mathrm{C}$ for $3 \mathrm{~d}$ before evaluation by the whole-cell patch-clamp technique.

Electrophysiological recordings. Immediately before recordings, individual coverslips were transferred to a $3 \mathrm{~cm}$ culture dish filled with recording solution consisting of (in $\mathrm{mM}$ ): $20 \mathrm{BaCl}_{2}, 65 \mathrm{CsCl}, 40$ TEA-Cl, 1 $\mathrm{MgCl}_{2}, 10$ glucose, and 10 HEPES, pH 7.2 (adjusted with TEA-OH). In some experiments, 20 or $2 \mathrm{~mm} \mathrm{CaCl} 2$ replaced $20 \mathrm{mM} \mathrm{BaCl}_{2}$. Pipettes (3-4 M 2 ; BF150-86-15 borosilicate glass; Sutter Instruments, Novato, CA) were pulled on a Sutter P-87 microelectrode puller, fire-polished with an MF-830 microforge (Narishige, Tokyo, Japan), and filled with filtered $(0.22 \mu \mathrm{m})$ intracellular recording solution consisting of (in $\mathrm{mm}$ ): 108 cesium methane sulfonate, $4 \mathrm{MgCl}_{2}, 9$ EGTA, and 9 HEPES, pH 7.2 (adjusted with $\mathrm{CsOH}$ ). For experiments examining calcium-dependent inactivation, and for recordings in low external calcium, "low EGTA" internal recording solution consisting of (in $\mathrm{mM}$ ) 118.5 cesium methane sulfonate, $1 \mathrm{MgCl}_{2}$, 0.5 EGTA, 9 HEPES, and $4 \mathrm{MgATP}$, pH 7.4 (adjusted with $\mathrm{CsOH}$ ), was used. Recordings were performed using an Axopatch 200B amplifier (Axon Instruments, Union City, CA) linked to a personal computer with either a Digidata 1322 A or a Digidata 1200 interface. pClamp version 9.1 was used for data acquisition. Currents were filtered at $1 \mathrm{kHz}$ and digitized at a minimum sampling frequency of $2 \mathrm{kHz}$. Series resistance was compensated by $80 \%$. The voltage dependence of inactivation was assessed by holding cells at various holding potentials for 10 $\mathrm{sec}$ before application of a test depolarization to $+20 \mathrm{mV}$. Currentvoltage relationships were obtained by holding cells at $-100 \mathrm{mV}$ before stepping to various test potentials or by ramping membrane voltage from -100 to $+50 \mathrm{mV}$ over $150 \mathrm{msec}$. $\omega$-Conotoxin GVIA (Sigma, St. Louis, $\mathrm{MO}$ ) was dissolved in water at a stock concentration of $1 \mathrm{mM}$. Nifedipine and BayK 8644 (Sigma) were dissolved in dimethylsulfoxide at a $10 \mathrm{~mm}$ stock concentration. Drugs were diluted from these stocks into the final recording solution immediately before recording and washed onto the cells using a gravity-driven microperfusion system.

Analysis of electrophysiological data was performed using Clampfit software and SigmaPlot 2000 (Jandel Scientific, Chicago, IL). Inactivation curves were fitted with modified Boltzman relationships $I=x+$ $(1-x) /\left(1+\exp \left(-z\left(V_{\mathrm{h}}-V\right) / 25.6\right)\right)$, where $I$ is the peak current amplitude, $x$ is the noninactivating fraction of current, $V$ is the test potential, $V_{\mathrm{h}}$ is the half-inactivation potential, and $z$ is a slope factor that reflects the effective gating charge. Whole-cell $I-V$ relationships were fitted with the equation $I=G\left(V-E_{\text {rev }}\right) /\left(1+\exp \left(\left(V_{\mathrm{a}}-V\right) / S\right)\right)$, where $G$ is the maximum slope conductance, $I$ is peak current amplitude, $V$ is the test potential, $V_{\mathrm{a}}$ is the half-activation potential, and $S$ is a slope factor. Error bars reflect SEs, and numbers in parentheses reflect the number of experiments. Statistical analysis was based on paired and unpaired Student's $t$ tests at the 0.05 significance level.

Tissue expression reverse transcription- $P C R$ reaction. To detect low levels of $\mathrm{Ca}_{\mathrm{v}} 1.4$ mRNA from different tissues, we used a total human RNA panel that contained RNA from 24 different tissues (Clontech) and a reverse transcription-PCR (RT-PCR) protocol. The reverse transcriptase reaction consisted of $1 \mu \mathrm{g}$ of total RNA, $1 \times$ reverse transcriptase buffer, $10 \mathrm{~mm}$ dNTPs, $5 \mathrm{U}$ of SuperScript reverse transcriptase (Invitrogen, San Diego, CA), and 10 pmol of oligonucleotide (5'-ctgagatgcccaagggctgc) at $42^{\circ} \mathrm{C}$ for $90 \mathrm{~min}$. From this reaction, $10 \mu \mathrm{l}$ was removed and added to a 50 $\mu l$ PCR. The PCR condition consisted of $10 \mu \mathrm{l}$ of reverse transcriptase reaction, $10 \times$ PCR buffer, 20 pmol of each oligonucleotide (5'- 
caatgcctgctactgggc and $5^{\prime}$ ctgagatgcccaagggctgc), $10 \mathrm{~mm} \mathrm{dNTP,} \mathrm{and} 2.5 \mathrm{U}$ of HotStar TaqDNA polymerase (Qiagen) heated for $95^{\circ} \mathrm{C}(15 \mathrm{~min})$, followed by 35 cycles of $94^{\circ} \mathrm{C}(30 \mathrm{sec}), 55^{\circ} \mathrm{C}(1 \mathrm{~min})$, and $74^{\circ} \mathrm{C}(2 \mathrm{~min})$. To confirm the PCR products were legitimate $\mathrm{Ca}_{\mathrm{v}} 1.4$-amplified products, the PCR products were electrophoresed through a 1.8\% agarose gel and then subjected to Southern blotting with a $\mathrm{Ca}_{\mathrm{v}} 1.4$-specific ${ }^{32} \mathrm{P}$ labeled oligonucleotide ( $5^{\prime}$-attgtacggtctgggcc). In addition, to verify all amplified bands were correct, all products were cloned into pGemT-easy vector (Promega, Madison, WI) and sequenced.

Antibody production and immunohistochemical staining. To examine $\mathrm{Ca}_{\mathrm{v}} 1.4$ distribution, a polyclonal antibody was produced using a fusion protein unique to the $\mathrm{Ca}_{\mathrm{v}} 1.4$ calcium channel as determined with a GenBank Basic Local Alignment Search Tool search (aa 1658-1723 of the human $\mathrm{Ca}_{\mathrm{v}} 1.4$ calcium channel carboxyl tail; GenBank accession number NM_005183). The portion of the channel carboxyl tail containing the fusion protein was cloned into the $\mathrm{pCX}$ vector and expressed using the Caulobactor expression system (Invitrogen) tagged with the Caulobactor RSA protein. The fusion peptide was injected into rabbits, whole serum was collected, and $\mathrm{Ca}_{\mathrm{v}} 1.4 / \mathrm{RSA}$ antibodies were IgA purified. Specificity of the $\mathrm{Ca}_{\mathrm{v}} 1.4$ antibody was determined by staining HEK cells transfected with each of the known neuronal calcium channel $\alpha_{1}$ subunits $\left(\mathrm{Ca}_{\mathrm{v}} 1.2\right.$, $\mathrm{Ca}_{\mathrm{v}} 1.3, \mathrm{Ca}_{\mathrm{v}} 1.4, \mathrm{Ca}_{\mathrm{v}} 2.1, \mathrm{Ca}_{\mathrm{v}} 2.2, \mathrm{Ca}_{\mathrm{v}} 2.3, \mathrm{Ca}_{\mathrm{v}} 3.1, \mathrm{Ca}_{\mathrm{v}} 3.2$, and $\left.\mathrm{Ca}_{\mathrm{v}} 3.3\right)$ plus $\beta_{2 \mathrm{a}}$ and $\alpha_{2}-\delta_{1}$ in the case of the high voltage-activated (HVA) channel complexes. Specific staining was seen only in cells transfected with the $\mathrm{Ca}_{\mathrm{v}} 1.4$ channel complex, and staining was abolished in the $\mathrm{Ca}_{\mathrm{v}} 1.4$ transfected cells when the antibody was preabsorbed with the blocking fusion protein (data not shown). For immunohistochemical staining, HEK tsA201 cells were transfected with the $\mathrm{Ca}_{\mathrm{v}} 1.4, \beta_{2 \mathrm{a}}$, and $\alpha_{2}-\delta_{1}$ antisera and then stained with the $\mathrm{Ca}_{\mathrm{v}} 1.4$ antisera. Briefly, transfected cells were grown for $3 \mathrm{~d}$ on poly-lysine-coated coverslips. The coverslips were washed two times with PBS, fixed in $3 \%$ paraformaldehyde (10 min), then followed by another two washes in PBS. To permeabilize the cells, the coverslips were transferred to $100 \%$ methanol for 2 min and then washed four times with fresh PBS. To hybridize the antibody to the fixed cells, $0.1 \mu \mathrm{g} / \mathrm{ml}$ of the $\mathrm{Ca}_{\mathrm{v}} 1.4$ antibody was added to PBS supplemented with $5 \%$ powdered milk and incubated at room temperature for at least 1 $\mathrm{hr}$. The coverslips had the primary antibody removed, followed by a wash (three times) for $5 \mathrm{~min}$ in PBS-1\% Triton X-100. The FITC-tagged secondary goat-anti rabbit antibody (Amersham) was added and hybridized $30 \mathrm{~min}$ in PBS supplemented with 5\% powdered milk. To remove any excess secondary antibody, the coverslips were washed three times in PBS-1\% Triton X-100 solution, air dried, and mounted on slides, and the images were captured with a confocal microscope.

For Western blotting, adult female rats were euthanized and decapitated, and various organs were removed and either used immediately or frozen in liquid nitrogen for later use. Various organs were ground and homogenized in $1 \mathrm{ml}$ of assay buffer (150 mM NaCl, 1\%NP-40, $0.5 \%$ deoxycholate, $0.1 \%$ SDS, $50 \mathrm{~mm}$ Tris, ph 7.5, and a mixture of protease inhibitors). The solution was incubated on ice for $1 \mathrm{hr}$ and centrifuged for $15 \mathrm{~min}\left(4^{\circ} \mathrm{C}\right)$ at $15,000 \times g$, and the supernatant was collected. Total protein concentration was determined with the modified Lowry assay, and $10 \mu \mathrm{g}$ of protein was combined with $10 \mu \mathrm{l}$ of $2 \times$ SDS loading buffer, boiled for $10 \mathrm{~min}$, and loaded onto a $\%$ acrylamide SDS-PAGE minigel. Proteins were electroblotted onto Hybond ECL nitrocellulose membrane (Amersham), air dried, and prehybridized overnight in 5\% powdered milk and $0.1 \%$ Tween 20 in PBS. Membranes were washed three times with PBS- $0.1 \%$ Tween 20 (PBST), followed by the addition of anti$\mathrm{Ca}_{\mathrm{v}} 1.4$ antibody $(1: 10,000)$ in PBST with $5 \%$ powdered milk. Hybridization of the $\mathrm{Ca}_{\mathrm{v}} 1.4$ antibody overnight at $4^{\circ} \mathrm{C}$ in PBST in $5 \%$ powdered milk was followed by three washes of PBST. A one hour incubation with the anti-rabbit antibody in PBST in 5\% powdered milk was followed by three washes in PBST, and the antibody was detected according to the $\mathrm{ECL}^{+}$kit protocol (Amersham). Western blots were repeated in triplicate, using 12 tissues each isolated from three separate rats.

Immunoperoxidase staining was performed on archival formalinfixed, paraffin-embedded human tissue obtained from Vancouver Hospital and Health Sciences Centre. Tissues assessed for $\mathrm{Ca}_{\mathrm{v}} 1.4$ calcium channel expression included retina, a retinoblastoma tumor, lymph node, thymus, spleen, and cervix. Eccentricity of the retina section could
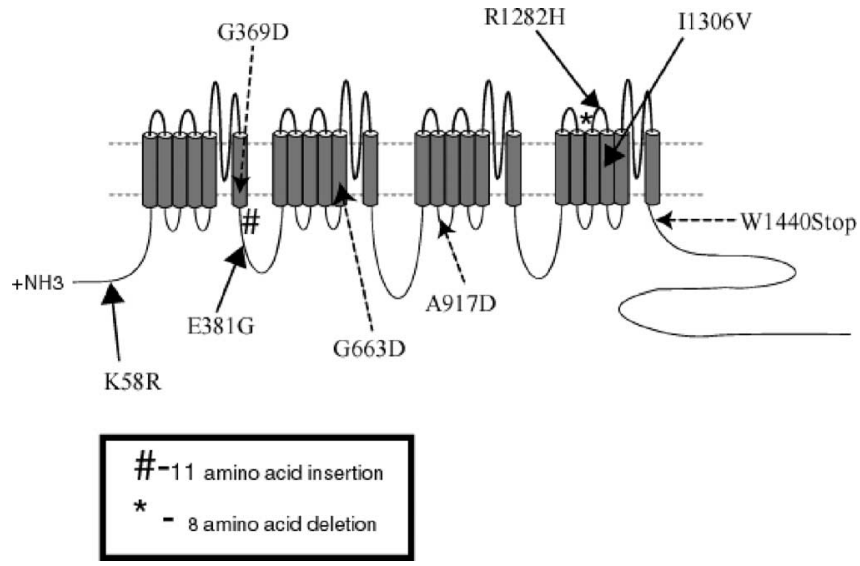

Figure 1. Proposed transmembrane topology of the calcium channel $\alpha_{1}$ subunit illustrating the approximate loci of amino acid differences in our CDNA construct relative to the previously available GenBank sequence (accession number AF15290). Lys-58 (N terminus) region, Glu-381 (domain I-II linker), Arg-1282 (IVS3-S4), and Ile-1306 (IVS4) in the original GenBank sequence are substituted in our CDNA by Arg, Gly, His, and Val residues, respectively. The presence of these residues was confirmed in five independent $P C R$ and sequencing reactions. The \# symbol indicates the location of an 11 amino acid insertion attributable to sliding of an intron-exon boundary at the end of exon 9 (domain I-II linker). The asterisk indicates a deletion of seven amino acids in the domain IV S3-S4 region attributable to skipping of exon 32. Locations of missense mutations associated with night blindness (G369D, G674D, A928D, W1459stop) are indicated by dotted lines.

not be determined because the sectioned globe showed complete detachment of the retina by retinoblastoma tumor. Tissue sections were cut at 4 $\mu \mathrm{m}$, placed on silanized glass slides, and baked at $60^{\circ} \mathrm{C}$ for $1 \mathrm{hr}$. They were deparaffinized in xylene and graded ethanol solutions, then rehydrated in double-distilled water. Antigen retrieval was performed by placing the slides in a Coplin jar filled with $10 \mathrm{~mm}$ citrate buffer, $\mathrm{pH}$ 6.0, and heating in a steamer at $60-90^{\circ} \mathrm{C}$ for $30-90 \mathrm{~min}$. The slides were cooled to room temperature and rinsed in PBS, pH 7.2-7.4, then endogenous peroxidase activity was blocked by incubation in a $3 \%(\mathrm{v} / \mathrm{v})$ aqueous hydrogen peroxide for $30 \mathrm{~min}$. Before immunostaining, blocking was performed by incubating the sections with $3 \%$ BSA for $30 \mathrm{~min}$. The primary antibody (rabbit polyclonal $\mathrm{Ca}_{\mathrm{v}} 1.4$ ) was applied at a dilution of 1:10,000, and incubation was performed in a sealed immunochamber at $4^{\circ} \mathrm{C}$ overnight. The antigen was detected by incubation for $25 \mathrm{~min}$ with a universal biotinylated secondary antibody labeled streptavidin-biotin-HRP system; Dako, Carpinteria, CA), followed by a 25 min incubation with streptavidin-HRP (LSAB-HRP system; Dako). Nova Red (Vector Laboratories, Burlingame, $\mathrm{CA}$ ) was used as the chromagen, and hematoxylin was used as the counterstain.

\section{Results}

The CACNA1F gene encodes a DHP-sensitive calcium channel with unique biophysical properties

Through a combination of library screening and RT-PCR, we isolated a cDNA clone from a human retinal cDNA library that encodes for a 1971 amino acid $\mathrm{Ca}_{\mathrm{v}} 1.4$ calcium channel. Compared with the previously reported CACNA1F sequence (GenBank accession number AF15290), our $\mathrm{Ca}_{\mathrm{v}} 1.4$ cDNA differed in several aspects: (1) there were four amino acid substitutions (K58R, E380G, R1282H, and I1306V); (2) there was an 11 amino acid insertion (Ser-Met-Ala-Glu-Glu-Gly-Arg-Ala-Gly-HisArg) in the domain I-II linker region attributable to sliding of the intron/exon boundary by 33 nucleotides into the intron at the end of exon 9; and (3) because of exon skipping of exon 32, there was the deletion of seven residues (Asp-Gly-Gly-His-Leu-GlyGlu) (Fig. 1).

To determine the functional characteristics of $\mathrm{Ca}_{\mathrm{v}} 1.4$, the full- 


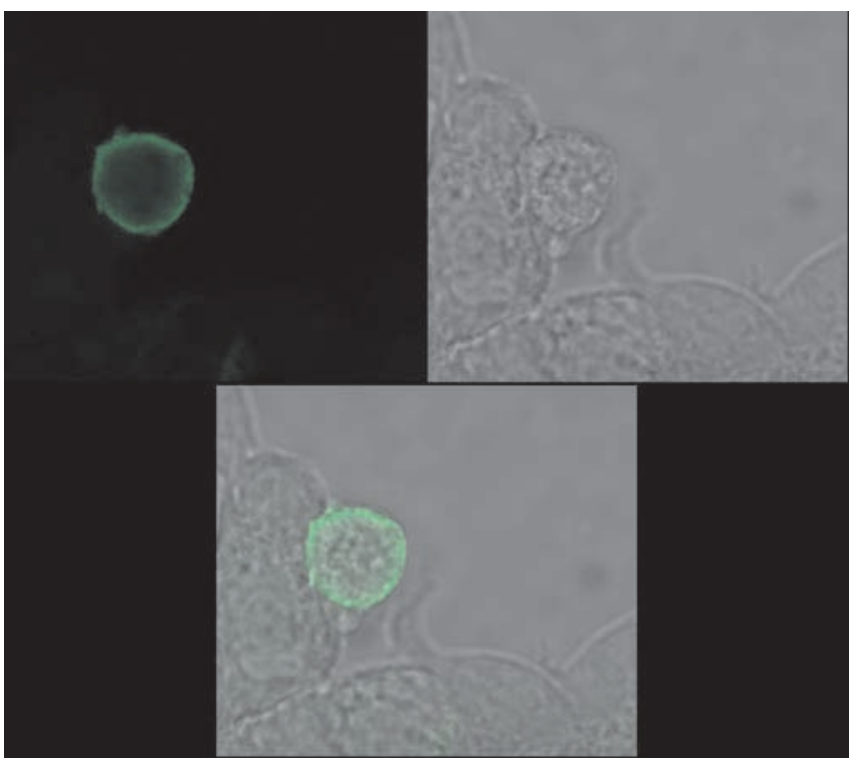

Figure 2. HEK cell transfected with human $\mathrm{Ca}_{v} 1.4$ cDNA/pcDNA 3-zeo and stained using the $C \mathrm{a}_{v} 1.4$ antibody. Top left, An image captured with a confocal microscope demonstrating expression of the $C \mathrm{a}_{\mathrm{v}} 1.4$ channel in the cell membrane. Top right, The same section, but visualized using bright-field illumination. Bottom, Overlay of above images demonstrating localization of the $C a_{v} 1.4$ calcium channel to the outer membrane.

length cDNA was transiently expressed in HEK 293 tsA-201 cells. To confirm protein expression and localization, an antibody to the human $\mathrm{Ca}_{\mathrm{v}} 1.4$ channel was designed against a unique stretch of residues (aa 1658-1723) contained within the C-terminal region. As shown in Figure 2, transfection of tsA-201 cells with $\mathrm{Ca}_{\mathrm{v}} 1.4$ (plus ancillary $\beta_{1 \mathrm{~b}}$ and $\alpha_{2}-\delta_{1}$ subunits) resulted in expression of the channel in the plasma membrane. In contrast, nontransfected cells did not exhibit any $\mathrm{Ca}_{\mathrm{v}} 1.4$ immunoreactivity, indicating that tsA-201 cells do not endogenously express $\mathrm{Ca}_{\mathrm{v}} 1.4$ protein.

To evaluate the functional properties of the human $\mathrm{Ca}_{\mathrm{v}} 1.4$ channel, the $\mathrm{Ca}_{\mathrm{v}} 1.4$ cDNA was transiently expressed in tsA-201 cells with $\beta_{2 \mathrm{a}}$ and $\alpha_{2}-\delta_{1}$ subunits plus an EGFP selection marker, and the characteristics of the channel were evaluated by wholecell patch clamp. The $\beta_{2 \mathrm{a}}$ subunit was used initially because of reports that knock-out of this calcium channel subunit, but not that of other calcium channel $\beta$ subunit isoforms, affects $\mathrm{Ca}_{\mathrm{v}} 1.4$ channel distribution in the outer plexiform layer of the retina and results in abnormal b waves in ERGs (Ball et al., 2002). Unless otherwise noted, electrophysiology data were obtained using an intracellular recording solution with $9 \mathrm{~mm}$ EGTA. When using 20 $\mathrm{mm}$ barium as the charge carrier, expression of $\mathrm{Ca}_{\mathrm{v}} 1.4$ resulted in robust, noninactivating inward currents that first activated near $-30 \mathrm{mV}$ and peaked at $\sim+15 \mathrm{mV}$ (Fig. $3 A, B$ ). The halfactivation potential obtained from fits to individual whole-cell current-voltage relationships was $-2.45 \pm 0.54 \mathrm{mV}(n=75)$, comparable with that observed with $\mathrm{Ca}_{\mathrm{v}} 1.2 \mathrm{~L}$-type calcium channels under similar recording conditions (Stotz et al., 2000). In contrast, the half-inactivation potential, $V_{\mathrm{h}}$, obtained from fits to individual inactivation curves was $-9.3 \pm 2.8 \mathrm{mV}(n=13)$, which is $\sim 15 \mathrm{mV}$ more positive than that observed with $\mathrm{Ca}_{\mathrm{v}} 1.2$ channels (Olcese et al., 1994; Stotz et al., 2000). The significantly more depolarized half-inactivation potential results in an unusually large window current (Fig. $3 C$ ) that spans a voltage range of $>40 \mathrm{mV}$, allowing the channel to be tonically active at these membrane potentials.
To test whether the $\mathrm{Ca}_{\mathrm{v}} 1.4$ channel would likely to be functional at typical resting potentials of rod photoreceptors, $20 \mathrm{~mm}$ external barium recording solution was replaced by $2 \mathrm{~mm}$ calcium recording solution, and a low $(0.5 \mathrm{~mm})$ EGTA internal recording solution with ATP was used (see Materials and Methods). $I-V$ relationships were obtained using a ramp protocol rather than a step protocol for convenience. As shown in Figure $3 D$, an ensemble of five ramp IV curves reveals that $\mathrm{Ca}_{\mathrm{v}} 1.4$ channels carry a small inward current at membrane potentials as negative as $-40 \mathrm{mV}$. The average half-activation potential obtained from the five cells was $-9.5 \pm 3.4 \mathrm{mV}$, and the slope factor, $S$, amounted to $8.42 \pm 0.82 \mathrm{mV}$. The average current size for the five cells tested in $2 \mathrm{~mm}$ calcium was $-80.7 \pm 35.9 \mathrm{pA}$ at peak. Taken together, these data suggest that transiently expressed $\mathrm{Ca}_{\mathrm{v}} 1.4 \mathrm{cal}-$ cium channels are capable of mediating calcium influx at typical photoreceptor resting potentials.

Figure $3 E$ examines the effects of coexpression of various types of calcium channel $\beta$ subunits on the biophysical properties of $\mathrm{Ca}_{\mathrm{v}} 1.4$ (bathed in $20 \mathrm{~mm}$ external barium). Interestingly, the calcium channel $\beta$ subunit subtype mediated only relatively minor $(\sim 5 \mathrm{mV})$ changes in half-inactivation and half-activation potentials. For $\beta_{1 \mathrm{~b}}$ and $\beta_{3}$, both $V_{\mathrm{h}}$ and $V_{\mathrm{a}}$ shifted into the same direction, thus predicting a similar size of window current as that seen with $\beta_{2 \mathrm{a}}$. For $\beta_{4}$, there was a somewhat larger separation between $V_{\mathrm{a}}$ and $V_{\mathrm{h}}$, predicting less window current and, thus, perhaps slightly less tonic activation. Most surprisingly, however, the time constant for inactivation did not significantly depend on the nature of the $\beta$ subunit coexpressed at any of the test potentials examined (ANOVA; $0.5>p>0.2$ ). In each case, the time constant for inactivation was found to be in the range of several seconds [i.e., $\tau_{\text {inactivation }}$ at $+10 \mathrm{mV} \beta_{1 \mathrm{~b}}=9.90 \pm 0.73 \mathrm{sec}(n=5)$, $\beta_{2 \mathrm{a}}=9.79 \pm 1.48 \mathrm{sec}(n=11), \beta_{3}=15.41 \pm 3.81 \mathrm{sec}(n=5), \beta_{4}$ $=12.34 \pm 1.68 \mathrm{sec}(n=9)]$. This is, to our knowledge, the first incidence in which HVA calcium channel kinetics are not significantly regulated by the nature of calcium channel $\beta$ subunits. In addition, these data imply that the slow inactivation properties illustrated in Figure $3 A$ is not simply attributable to the presence of a $\beta$ subunit that is known to generally antagonize the voltagedependent inactivation of all other known HVA calcium channels (Olcese et al., 1994). Nonetheless, the observation that the time course of inactivation was slow irrespective of the type of $\beta$ subunit coexpressed is consistent with the notion that in photoreceptors the calcium channels would need to be open for prolonged periods to allow for the tonic secretion of transmitter in the dark.

Figure $4 \mathrm{~A}$ illustrates the effects of calcium ions on $\mathrm{Ca}_{\mathrm{v}} 1.4$ channel activity. In the presence of low EGTA $(0.5 \mathrm{~mm})$ internal solution, switching from $20 \mathrm{~mm}$ Ba to $20 \mathrm{~mm}$ Ca resulted in a reduction in peak current amplitude. Strikingly, however, no calcium-dependent inactivation was apparent. The fraction of current remaining (R800) after an 800 msec depolarization to $+20 \mathrm{mV}$ did not differ significantly in barium and in calcium in seven cells examined (Fig. $4 A$, inset; paired $t$ test). No significant decrease in $\mathrm{R} 800$ between barium and calcium was observed for any of the other test potentials examined $(0,10$, or $30 \mathrm{mV}$; data not shown). This result contrasts with recent findings obtained with N-type and R-type calcium channels (Liang et al., 2003) and makes $\mathrm{Ca}_{\mathrm{v}} 1.4$ the only HVA calcium channel that does not display calcium-dependent inactivation. Moreover, these data indicate that even in the presence of calcium ions, $\mathrm{Ca}_{\mathrm{v}} 1.4$ channels are capable of sustained openings. 

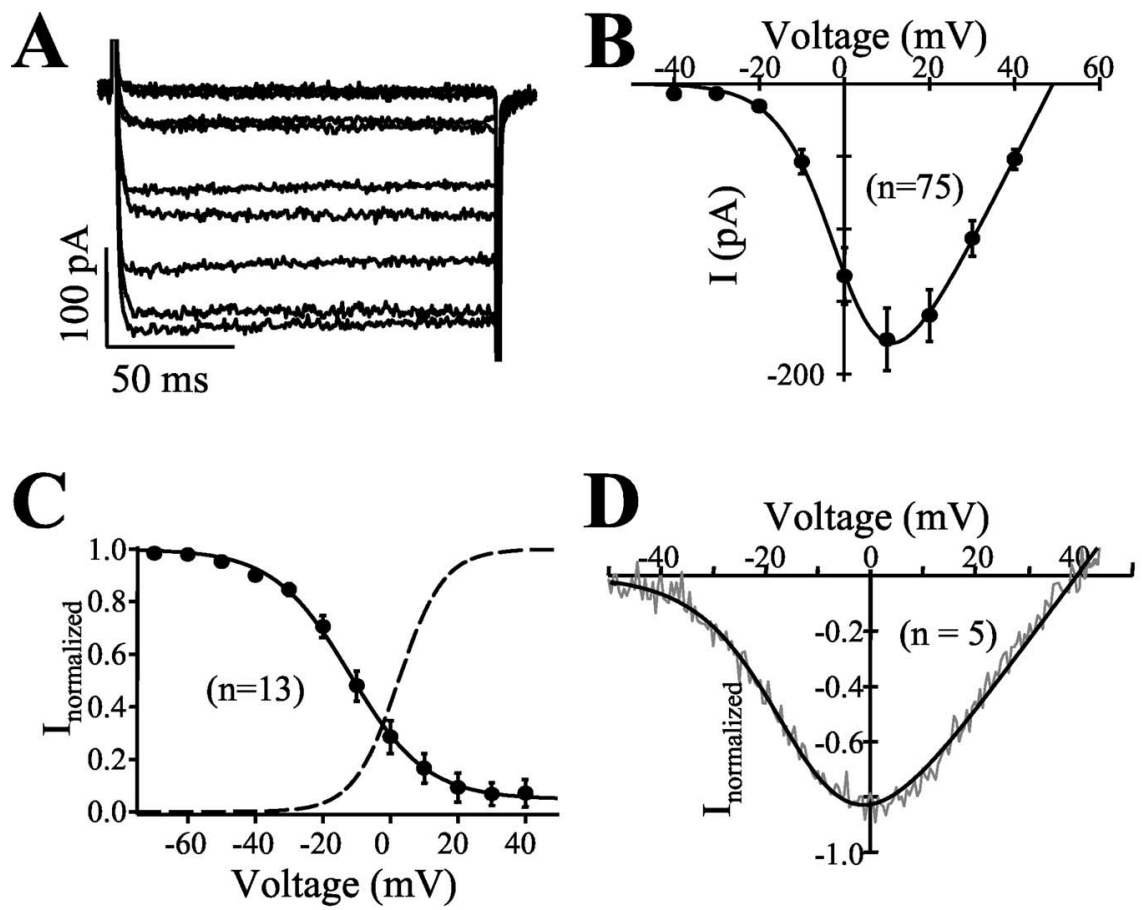

E
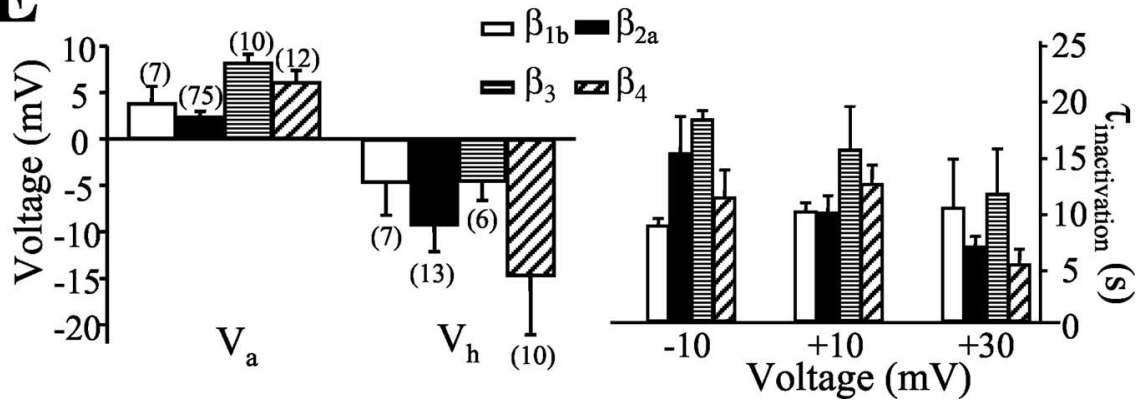

Figure 3. Biophysical properties of the human $\mathrm{Ca}_{\mathrm{v}} 1.4$ calcium channel. $A$, Family of whole-cell currents recorded from the human $\mathrm{Ca}_{\mathrm{v}} 1.4$ calcium channel coexpressed with rat $\beta_{2 \mathrm{a}}$ and $\alpha_{2}-\delta_{1}$ subunits in ts $\mathrm{A}-201$ cells. The cell was held at $-100 \mathrm{mV}$ and depolarized to various test potentials at 10 sec intervals. $B$, Ensemble of whole-cell current-voltage relationships from 75 different experiments. In each case, the holding potential was $-100 \mathrm{mV}$. The solid line reflects a fit with the Boltzman relationship. Parameters obtained from this fit were: $G=5.7 \mathrm{nS}, S=6.68 \mathrm{mV}, E_{\text {rev }}=49.0 \mathrm{mV}$, and $V_{\mathrm{a}}=-0.95 \mathrm{mV}$. C, Ensemble of 14 inactivation curves obtained at a test potential of $+20 \mathrm{mV}$. The solid line is a fit with the Boltzmann relationship. The parameters obtained from the fit were: $V_{\mathrm{h}}=-11.98 \mathrm{mV}$ and $z=2.26$. The dashed line represents the activation curve plotted using parameters obtained in $B$. Note the large window current. $D$, Activity of $C_{\mathrm{v}} 1.4$ in $2 \mathrm{~mm} \mathrm{Ca}{ }^{2+}$ and low (0.5 mm) EGTA internal recording solution containing $4 \mathrm{~mm}$ ATP. The light trace represents an average of $I-V$ relationships obtained from five separate recordings, each normalized to unity at peak. Because the individual / $-V$ relationships did not peak at exactly the same potential, the peak of the displayed $I-V$ curves and its Boltzmann fit (solid line) do not extend to -1 . The fitting parameters were: $V_{\mathrm{a}}=$ $-11.0 \mathrm{mV}, E_{\mathrm{rev}}=38.1 \mathrm{mV}, \mathrm{G}=0.028 \mathrm{nS}$, and $S=8.65 \mathrm{mV}$. $E$, Comparison of the biophysical parameters of the human $C \mathrm{a}_{\mathrm{v}} 1.4$ calcium channel coexpressed with rat $\alpha_{2}-\delta_{1}$ and various rat $\beta$ subunits ( $20 \mathrm{~mm} \mathrm{Ba}$ ). Note that the $\beta$ subunits mediate only minor changes in the half-activation $\left(V_{a}\right)$ and half-inactivation potentials $\left(V_{h}\right)$ and in the time constants for inactivation (determined from monoexponential fits to raw current records such as the one shown in $D)$.

Figure $4 B$ shows that the $\mathrm{Ca}_{\mathrm{v}} 1.4$ channel was sensitive to low concentrations of the DHP antagonist nifedipine, such that at a holding potential of $-100 \mathrm{mV}$, block occurred with an $\mathrm{IC}_{50}$ value of $944 \pm 127 \mathrm{~nm}(n=10)$. Holding the cells at a more depolarized membrane potential resulted in a small, but statistically significant, increase in the amount of block mediated by $300 \mathrm{~nm}$ nifedipine from $35.4 \pm 5.5 \%(n=11)$ to $43.4 \pm 5.3 \%(n=4, p=$ 0.01 ), consistent with the notion that DHP block of L-type channels is state dependent. Application of the DHP agonist BayK 8644 resulted in a pronounced upregulation of current activity (Fig. 4C), increasing the maximum slope conductance fourfold from $2.69 \pm 0.37$ to $9.48 \pm 1.63 \mathrm{nS}(n=9)$ and shifting the half-activation potential from $-1.28 \pm 1.52$ to $-12.03 \pm 1.87 \mathrm{mV}$ $(n=9)$. Overall, the $\mathrm{Ca}_{\mathrm{v}} 1.4$ channel indeed behaves pharmacologically similar to other native and cloned L-type calcium channels. Figure 4D summarizes other aspects of the pharmacological profile of $\mathrm{Ca}_{\mathrm{v}}$ 1.4. The channel was mildly inhibited by application of $3 \mu \mathrm{M} \omega$-conotoxin GVIA ( $\sim 20 \%$ inhibition), consistent with findings in salamander rod photoreceptors (Wilkinson and Barnes, 1996). As expected for an HVA calcium channel, 10 $\mu \mathrm{M}$ cadmium completely inhibited current activity within $15 \mathrm{sec}$ of application (Fig. 4D).

\section{Effects of mutations associated with night blindness on $\mathrm{Ca}_{\mathrm{v}} 1.4$ function} A number of mutations in the CACNA1F gene have been associated with CSNB2 (Boycott et al., 2000). Most of the mutations result in premature stop codons in the four major transmembrane domains or intracellular linker regions and would be predicted to result in the complete loss of $\mathrm{Ca}_{\mathrm{v}} 1.4$ channel function in rod photoreceptors. Additionally, a number of patients also seem to carry missense mutations in the CACNA1F gene including substitution of glycine residues found in the IS6 and IIS5 segments and an alanine in the domain IIIS1-S2 linker region to aspartic acid (Boycott et al., 2000). To determine how the various mutations might contribute the clinical phenotype, we created three CSNB2 missense mutations in distinct regions in the $\mathrm{Ca}_{\mathrm{v}} 1.4$ channel. In addition, we generated a CSNB2 mutation that results in the replacement of a tryptophan residue at the beginning of the carboxyl terminal tail region with a premature stop codon. Interestingly, two of the missense mutations (G674D and A928D) and the W1459 premature stop in the carboxyl tail appeared to exert no detectable changes in the activation, inactivation, or conductance properties of the $\mathrm{Ca}_{\mathrm{v}} 1.4 \mathrm{cal}$ cium channel (Table 1). In contrast, the G369D mutation resulted in statistically significant changes in the slope of activation $(S)$ and in the difference in half-activation potential obtained in barium and calcium compared with the wild-type $\mathrm{Ca}_{\mathrm{v}} 1.4$ channel. The notion that deletion of virtually the entire carboxyl terminus region had little effect on channel function is particularly surprising in view of previous work in other types of L-type calcium channels, showing that this region is an essential regulatory domain and required for proper function (Peterson et al., 1999; DeMaria et al., 2001). Taken together, these data suggest that the clinical phenotype associated with some alterations in the CACNA1F gene may not arise simply from altered biophysical properties of the channel. 
Expression of $\mathrm{Ca}_{\mathrm{v}} 1.4$ in human retina To date, $\mathrm{Ca}_{\mathrm{v}} 1.4$ protein distribution has only been examined in rodents and revealed $\mathrm{Ca}_{\mathrm{v}} 1.4$ immunoreactivity in the outer plexiform layers and colocalization with protein bassoon (Morgans, 2001; Morgans et al., 2001; Berntson et al., 2003). There has been no description of $\mathrm{Ca}_{\mathrm{v}} 1.4$ distribution in human retina, although, based on the notion that point mutations in the $\mathrm{Ca}_{\mathrm{v}} 1.4$ calcium channel result in CSNB2, it might be expected that $\mathrm{Ca}_{\mathrm{v}} 1.4$ channels comprise a major portion of the L-type calcium current in rod photoreceptors. Shown in Figure $5 A$ is a tissue section of human retina stained with hematoxylin and eosin ( $\mathrm{H}$ and $\mathrm{E}$ ) demonstrating the constituents of the retina. Staining of human retina with the $\mathrm{Ca}_{\mathrm{v}} 1.4$ specific antibody (Fig. $5 B$ ) revealed channel expression (brown precipitate) in the outer plexiform layer, consistent with localization of the channels in photoreceptors. Additional $\mathrm{Ca}_{\mathrm{v}} 1.4$ staining was evident in the inner nuclear layer, inner plexiform layer, and nerve fiber layer. $\mathrm{Ca}_{\mathrm{v}} 1.4$ staining is distinct and not as widespread from that reported for other HVA calcium channels with $\mathrm{P} / \mathrm{Q}-, \mathrm{N}-$, and other L-type calcium channels present in the additional layers of the retina (Xu et al., 2002 ). Figure $5 C$ is a negative control tissue section of retina and retinoblastoma tumor stained with preabsorbed $\mathrm{Ca}_{\mathrm{v}} 1.4$ antibody, showing that the antibody reactivity has been abolished.

The retina sample depicted in Figure 5 was obtained from a retinoblastoma patient whose retina was displaced by the invasive tumor. Figure 6 illustrates $\mathrm{Ca}_{\mathrm{v}} 1.4$ immunoreactivity in a retinal section from the same patient, but magnified to include the tumor tissue. Figure $6 A$ is a tissue section of human retina stained with $\mathrm{H}$ and $\mathrm{E}$ demonstrating the constituents of the retinoblastoma tumor. As shown in Figure $6 B$, there was intense $\mathrm{Ca}_{\mathrm{v}} 1.4$ staining throughout the retinoblastoma, except within the necrotic region and the blood vessel. As shown in Figure 6C, a negative control tissue section of retina and retinoblastoma tumor stained with preabsorbed $\mathrm{Ca}_{\mathrm{v}} 1.4$ antibody and counterstained with $\mathrm{H}$ and $\mathrm{E}$ did not yield $\mathrm{Ca}_{\mathrm{v}} 1.4$ immunoreactivity. This result suggests the possibility that $\mathrm{Ca}_{\mathrm{v}} 1.4$ channel expression is either upregulated during tumor growth or, alternatively, that the channel might mediate a role in the development of retinoblastoma per se.

\section{Tissue distribution of $\mathrm{Ca}_{\mathrm{v}} 1.4 \mathrm{mRNA}$ and protein}

To examine the distribution of $\mathrm{Ca}_{\mathrm{v}} 1.4$ expression, we performed RT-PCR analysis of mRNA derived from 24 different human tissues. No $\mathrm{Ca}_{\mathrm{v}} 1.4$ message was detected in RNA isolated from whole brain, heart, colon, fetal brain, fetal liver, kidney, lung, liver, mammary gland, pancreas, placenta, prostate, salivary gland, small intestine, stomach, testis, trachea, and the uterus. In contrast, $\mathrm{Ca}_{\mathrm{v}} 1.4$ expression could be detected in RNA isolated

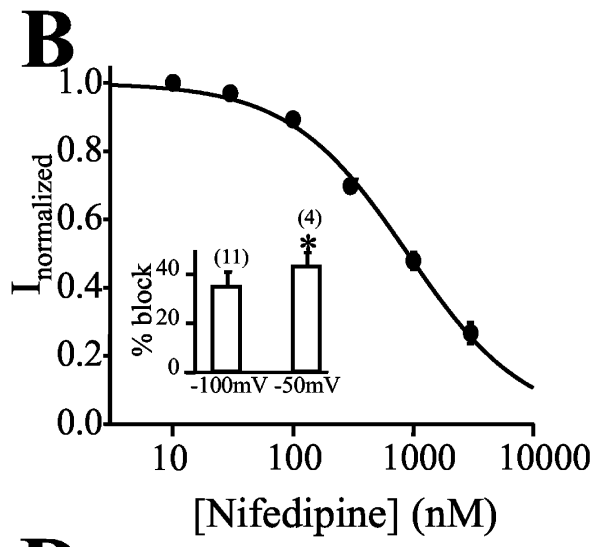

D

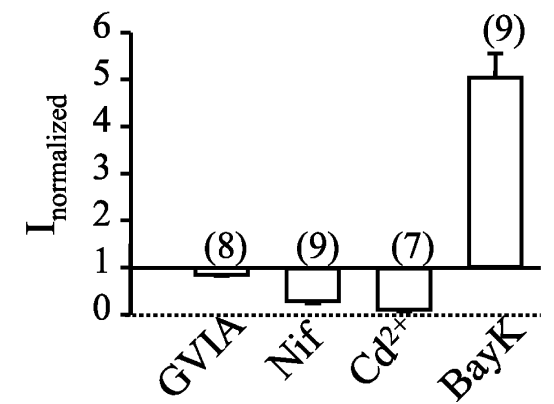

- $20 \mathrm{mM} \mathrm{Ba}^{2+}$ - $3 \mu \mathrm{M}$ BayK

Figure 4. Pharmacological properties of human $\mathrm{Ca}_{\mathrm{v}} 1.4$ calcium channels. $A$, Sample traces at $+20 \mathrm{mV}$ for currents obtained in $20 \mathrm{~mm}$ external ion in the presence of low $(0.5 \mathrm{~mm})$ EGTA internal recording solution. Note that even under low buffering ifedipine block of $\mathrm{Ca}_{v} 1.4$ channels (coexpressed with rat $\beta_{2 a}$ and rat $\left.\alpha_{2}-\delta_{1}\right)$ at a test potential of $+20 \mathrm{mV}(\mathrm{n}=10)$. The solid ine reflects a fit with the Michaelis-Menton equation $\left(\mathrm{IC}_{50}=900 \mathrm{~nm} ; n=0.88\right)$. Inset, Comparison of the blocking effects of 300 after the application of $3 \mu \mathrm{m}$ BayK8644. In each case, the holding potential was $-100 \mathrm{mV}$. Note the increase in maximum slope dhe peak of the current-voltage relationship after application of BayK 8644. The parameters

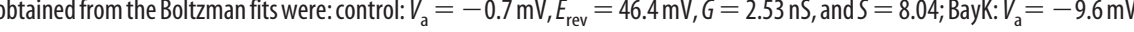
the small degree of inhibition mediated by $3 \mu \mathrm{m} \omega$-conotoxin GVIA $(17.4 \pm 0.9 \% ; n=8)$. Nifedipine $(3 \mu \mathrm{m})$ and cadmium (10 $\mu \mathrm{m})$ both potently inhibit channel activity $[73.4 \pm 3.1 \%(n=9)$ and $91.2 \pm 2.0 \%(n=7)$ block, respectively]. BayK $8644(3 \mu \mathrm{M})$ significantly upregulates current activity $(406 \pm 50 \% ; n=9)$.

from the spleen, thymus, adrenal gland, spinal cord, bone marrow, and skeletal muscle (Fig. 7A). These data indicate that mRNA encoding $\mathrm{Ca}_{\mathrm{v}} 1.4$ is not exclusively transcribed in retinal tissue. To further examine these findings at the protein level, we performed Western blot analysis on protein homogenates isolated from 12 rat tissues, each from three separate rats. As shown in Figure $7 B, \mathrm{Ca}_{\mathrm{v}} 1.4$ protein expression was detected by the antibody hybridizing to a single specific band $(\sim 220 \mathrm{kDa})$ in wholecell protein lysate isolated from rat retina as well as from the spleen, spinal cord, bone marrow, and thymus. No antibody hybridization was seen in the protein sample isolated from the heart, whole brain, liver, intestine, ovary, lung, and kidney.

The finding of $\mathrm{Ca}_{\mathrm{v}} 1.4$ expression in both rat and human lymphoid tissues was of particular interest, and additional immunostaining was performed on tissue sections of human lymph node, thymus, and spleen. Figure $8 \mathrm{~A}$ shows intense $\mathrm{Ca}_{\mathrm{v}} 1.4$ positive staining (brown precipitate) of plasma cells within lymph node germinal centers. Other B lymphocytes (i.e., follicle center cells and mantle cells) and T lymphocytes did not interact with the 
Table 1. Biophysical properties of wild-type versus night blindness $\mathrm{Ca}_{\mathrm{v}} 1.4$ mutations

\begin{tabular}{|c|c|c|c|c|c|}
\hline & $C a_{v} 1.4$ & $C a_{v} 1.4 G 369 D$ & $\mathrm{Ca}_{\mathrm{v}} 1.4 \mathrm{G} 674 \mathrm{D}$ & $\mathrm{Ca}_{v} 1.4$ A928D & $\begin{array}{l}\mathrm{Ca}_{\mathrm{v}} 1.4 \\
\text { W1459Stop }\end{array}$ \\
\hline Activation & $n=75$ & $n=25$ & $n=16$ & $n=21$ & $n=33$ \\
\hline$V_{a}(m V)$ & $2.45 \pm 0.54$ & $4.17 \pm 0.83$ & $3.83 \pm 1.32$ & $3.48 \pm 1.10$ & $2.07 \pm 1.01$ \\
\hline$S(m V)$ & $6.67 \pm 0.14$ & $7.49 \pm 0.25^{*}$ & $6.74 \pm 0.20$ & $7.20 \pm 0.32$ & $6.62 \pm 0.16$ \\
\hline$G(n S)$ & $5.62 \pm 0.54$ & $3.53 \pm 0.66$ & $6.42 \pm 1.49$ & $6.13 \pm 1.95$ & $6.47 \pm 0.98$ \\
\hline Inactivation & $n=13$ & $n=13$ & $n=12$ & $n=16$ & $n=12$ \\
\hline$V_{\mathrm{h}}(\mathrm{mV})$ & $-9.30 \pm 2.78$ & $-2.46 \pm 1.58$ & $-5.41 \pm 3.02$ & $-7.34 \pm 2.83$ & $-2.78 \pm 2.38$ \\
\hline$z$ & $2.40 \pm 0.14$ & $2.03 \pm 0.15$ & $2.29 \pm 0.18$ & $2.31 \pm 0.16$ & $2.05 \pm 0.10$ \\
\hline$\tau_{+10 \mathrm{mV}}(\mathrm{sec})$ & $9.79 \pm 1.48$ & $14.34 \pm 2.26$ & $17.63 \pm 3.61$ & $14.80 \pm 2.62$ & $17.19 \pm 2.99$ \\
\hline$B a$ versus $C a$ & $n=9$ & $n=6$ & $n=6$ & $n=6$ & $n=8$ \\
\hline \multicolumn{6}{|l|}{$\mathrm{Va}_{\mathrm{Ba}}-\mathrm{Va}_{\mathrm{Ca}}$} \\
\hline$(\mathrm{mV})$ & $-11.24 \pm 0.64$ & $-4.28 \pm 1.47^{*}$ & $-9.73 \pm 1.36$ & $-8.89 \pm 1.21$ & $-9.94 \pm 1.23$ \\
\hline $\mathrm{G}_{\mathrm{Ba}}: \mathrm{G}_{\mathrm{Ca}}$ & $1.72 \pm 0.11$ & $1.84 \pm 0.18$ & $1.80 \pm 0.17$ & $1.70 \pm 0.14$ & $1.85 \pm 0.14$ \\
\hline
\end{tabular}

The data were obtained as outlined in Figures 3 and 4 , using $9 \mathrm{~mm}$ EGTA internal solutions. All Cav 1.4 subunits were coexpressed with calcium channel $\alpha_{2}-\delta_{1}$ and $\beta_{2 a}$ subunits. Data are presented as the means \pm SEM, and the number of experiments is shown. ${ }^{*} p<0.05$ compared with wild-type Cay 1.4 ; one-way ANOVA post hoc Tukey's test.

$\mathrm{Ca}_{\mathrm{v}} 1.4$ antibody. In addition, a subset of mast cells in the perinodal soft tissue stained strongly positive. Within thymic and splenic tissue, only rare cells stained positively, and definite morphological identification of these cells was not possible.

In surgical pathology, $\mathrm{H}$ and $\mathrm{E}$ staining is often used to assess tissue morphology and cytologic detail. Hematoxylin, with its net-positive charge, stains negatively charged material, including the genetic material in nuclei (blue/purple). Eosin, with its netnegative charge, stains positively charge intracellular material, such as cytoskeletal elements and cytoplasmic proteins (pink/ red). With $\mathrm{H}$ and $\mathrm{E}$ staining, plasma cells appear as round to oval cells measuring $\sim 14-20 \mu \mathrm{m}$ in size. The nucleus is small relative to the volume of cytoplasm, eccentrically placed, and characteristically has moderate amounts of condensed chromatin, giving an appearance reminiscent of a "clock face." The cytoplasm of plasma cells is typically eosinophilic (pink) or amphophilic (purplish), and a pale paranuclear area corresponding to the Golgi apparatus is characteristic. Mast cells are similar in size or slightly larger than plasma cells and with $\mathrm{H}$ and $\mathrm{E}$ stain appear oval or polygonal in shape. The cytoplasm is characteristically granular and more eosinophilic (reddish) in comparison with plasma cells. The nucleus may be centrally or eccentrically placed, but the chromatin is typically more evenly distributed, and paranuclear clearing is not a feature in comparison with plasma cells. To confirm expression of $\mathrm{Ca}_{\mathrm{v}} 1.4$ calcium channels in plasma and mast cells, a section of uterine cervix showing chronic cervicitis, with abundant plasma cell and mast cell infiltrates, was stained (Fig. 8 B). Similar to that for lymph nodes, intense positive staining (brown precipitate) of plasma and mast cells was observed (Fig. $8 B$ ). As shown in Figure $8 C$, a control tissue section (i.e., uterine cervix) stained with preabsorbed $\mathrm{Ca}_{\mathrm{v}} 1.4$ antibody and counterstained with $\mathrm{H}$ and $\mathrm{E}$ did not yield $\mathrm{Ca}_{\mathrm{v}} 1.4$ immuoreactivity. Taken together, these data indicate that the $\mathrm{Ca}_{\mathrm{v}} 1.4 \mathrm{~L}$-type calcium channel is more widely expressed than originally believed and suggest that it may play an as yet to be defined role in the immune system.

\section{Discussion}

\section{Biophysical properties of the $\mathrm{Ca}_{\mathrm{v}} 1.4$ calcium channel}

Calcium currents in rod and cone inner segments have remained relatively poorly characterized because of the difficulty in dissociating and isolating photoreceptors with intact inner segments and because of their small size in most species used for physiological analysis. In particular, there is no information concerning the ionic currents in human photoreceptors. Perhaps the most complete description of ionic currents in photoreceptors comes from work in tiger salamander retina (Corey et al., 1984; Barnes and Hille, 1989; Barnes, 1994; Kurenny et al., 1994; Matthews, 1995; Wilkinson and Barnes, 1996; Akopian et al., 2000; Kourennyi and Barnes 2000; Thoreson and Stella, 2000). Corey et al. (1984) reported that whole-cell calcium currents in salamander rod photoreceptors first activated at $\sim-40 \mathrm{mV}$ and peaked at $\sim 0$ $\mathrm{mV}$. The current size increased when barium replaced calcium. In the presence of $10 \mathrm{~mm}$ internal EGTA, currents carried by both barium and calcium remained sustained over the course of several seconds, although a small degree of calcium-dependent inactivation became apparent on reducing internal EGTA to 0.1 mM. Kurenny et al. (1994) reported similar biophysical properties for rod L-type calcium currents and also showed a pronounced current enhancement in the presence of the nitric oxide donor S-nitrocysteine. Salamander rod photoreceptor currents are sensitive to DHP antagonists (Barnes, 1994; Thoreson et al., 1997) and show some sensitivity to the N-type calcium channel blocker $\omega$-conotoxin GVIA (for review, see Barnes and Kelly, 2003). Although it has been suggested that L-type calcium currents in cone photoreceptors are carried primarily by $\mathrm{Ca}_{\mathrm{v}} 1.3 \mathrm{cal}-$ cium channels (Taylor and Morgans, 1998), the notion that mutations in $\mathrm{Ca}_{\mathrm{v}} 1.4$ calcium channels result in defects in rod vision (Bech-Hansen et al., 1998a,b; Strom et al., 1998) strongly suggests that the rod L-type currents are predominantly attributable to $\mathrm{Ca}_{\mathrm{v}} 1.4$, an idea that is supported by our data showing $\mathrm{Ca}_{\mathrm{v}} 1.4$ immunoreactivity in retina layers associated with human rod cells.

Our data in many ways parallel the results of Corey et al. (1984) and of findings in mammalian bipolar cells (de la Villa et al., 1998; Protti and Llano, 1998). Similar to salamander rod L-type currents, human $\mathrm{Ca}_{\mathrm{v}} 1.4$ channels showed prolonged openings over several seconds, exhibited larger whole-cell currents in barium compared with calcium, and did not possess calcium-sensitive inactivation in the presence of low internal EGTA. The slight inhibition of $\mathrm{Ca}_{\mathrm{v}} 1.4$ by $\omega$-conotoxin GVIA and complete block by cadmium are also consistent with prior work in salamander rods (Barnes and Kelly, 2004). Calcium currents recorded by Protti and Llano (1998) from bipolar cells in rat retinal slices in $2 \mathrm{mM} \mathrm{Ca}^{2+}$ showed activation thresholds of -40 $\mathrm{mV}$ and negligible inactivation over the course of hundreds of milliseconds and were sensitive to DHPs, including nifedipine and BayK 8644. de la Villa et al. (1998) identified a transient current in mouse bipolar cells that activated at potentials near 

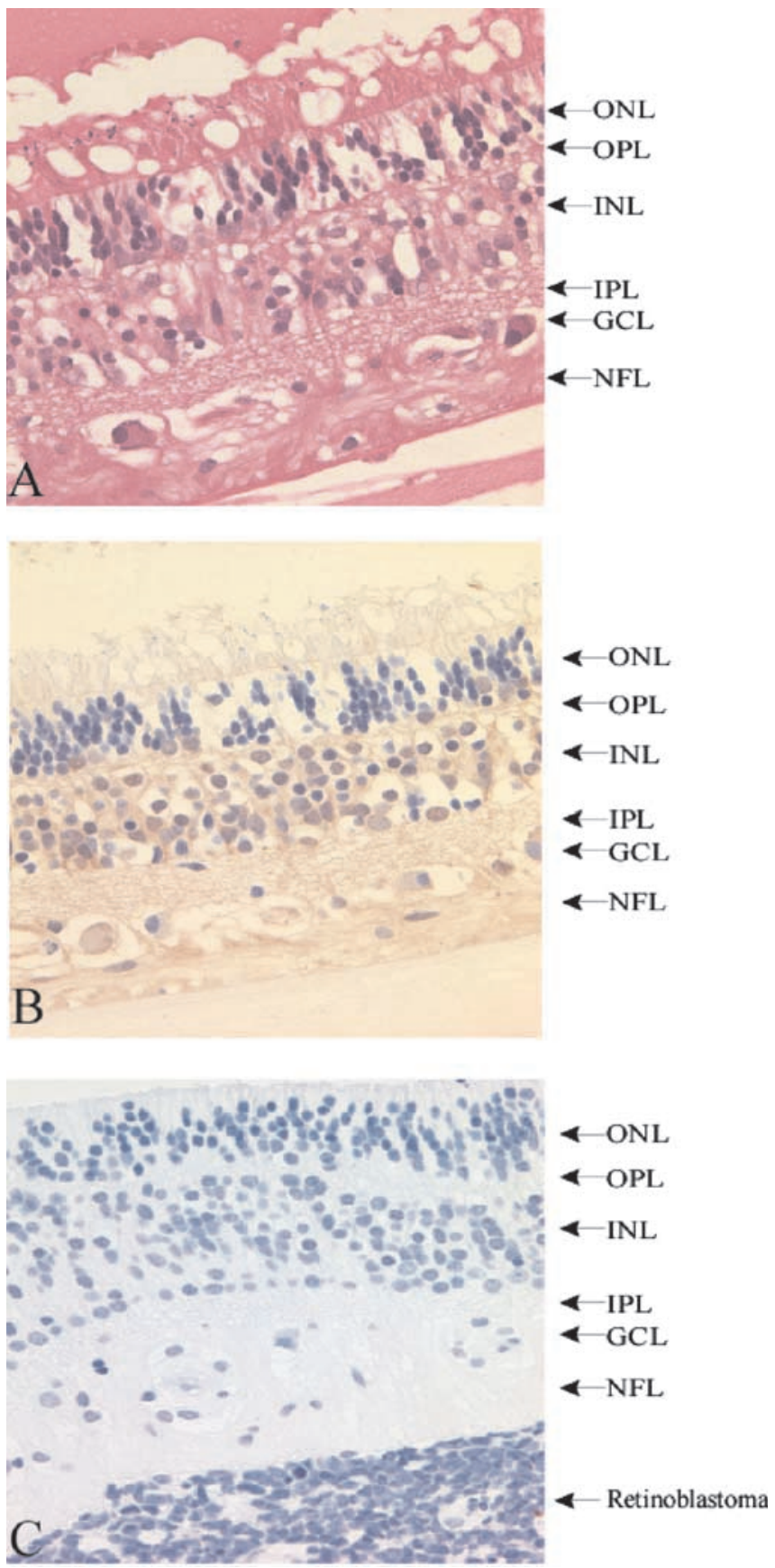

Figure 5. Expression of the $\mathrm{Ca}_{\mathrm{v}} 1.4$ calcium channel in human retina. $A$, Tissue section of human retina stained with $\mathrm{H}$ and $\mathrm{E}$ demonstrating the constituents of the retina. ONL, Outer nuclear layer; $\mathrm{OPL}$, outer plexiform layer; $\mathrm{INL}$, inner nuclear layer; IPL, inner plexiform layer; $\mathrm{GCL}$, ganglion cell layer; $\mathrm{NFL}$, nerve fiber layer. $B$, Tissue section of retina immunostained with $\mathrm{Ca}_{\mathrm{v}} 1.4$ antibody (staining indicated by brown precipitate). Immunoreactivity of cells and synapses is observed in the OPL, INL, IPL, and NFL. C, Tissue section of retina and retinoblastoma tumor stained with preabsorbed $\mathrm{Ca}_{v} 1.4$ antibody (negative control). All images were captured at $400 \times$ magnification.

$-40 \mathrm{mV}$, showed no sign of time-dependent inactivation, was more permeable to barium ions than calcium, and showed high sensitivity to DHPs but not $\omega$-conotoxin GVIA. Thus, human $\mathrm{Ca}_{\mathrm{v}} 1.4$ currents show the same characteristics as native calcium currents recorded in mouse and rat bipolar cells, as well as salamander rods, and our staining of retinal sections show that $\mathrm{Ca}_{\mathrm{v}} 1.4$ is localized in regions in human retina in which rod and bipolar cells are located. In support of the biophysical properties
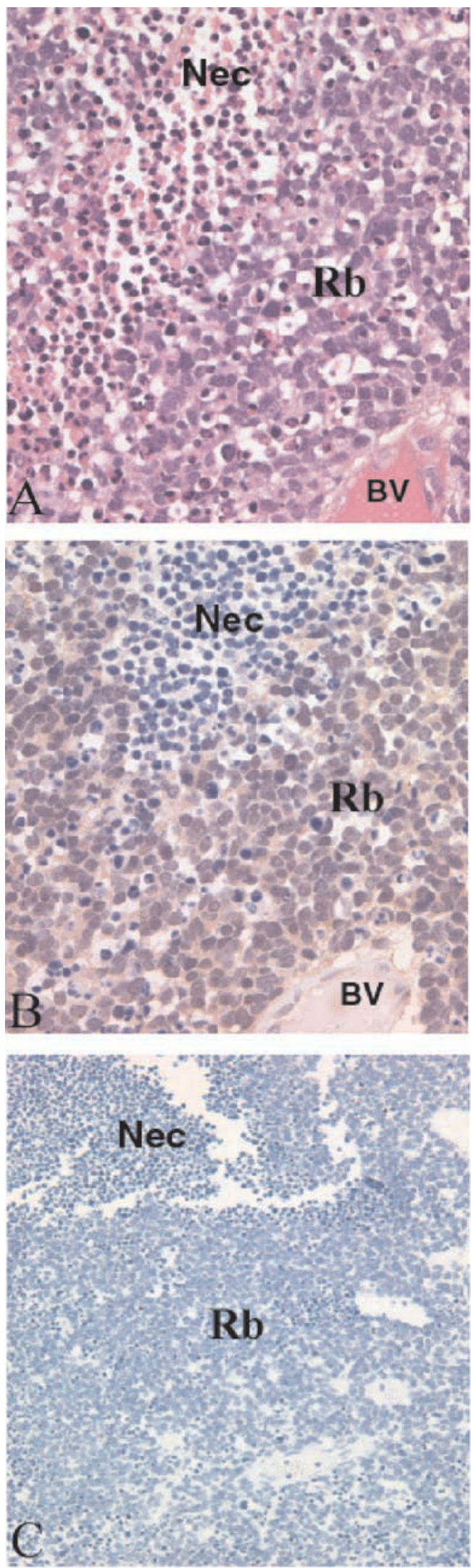

Figure 6. Expression the $\mathrm{Ca}_{\mathrm{v}} 1.4$ calcium channel in human retinoblastoma (Rb). A tissue section of human $\mathrm{Rb}$ tumor $(400 \times)$ stained with $\mathrm{H}$ and $\mathrm{E}(A)$ and with $\mathrm{Ca}_{v} 1.4$ antibody $(B)$ (staining indicated brown precipitate) demonstrating immunoreactivity of tumor cells is shown. Areas of tumor cell necrosis (Nec) and endothelial cells lining the blood vessel (BV) do not stain. C, Section of $\mathrm{Rb}(200 \times)$ stained with preabsorbed $\mathrm{Ca}_{\mathrm{v}} 1.4$ antibody (negative control). 
A

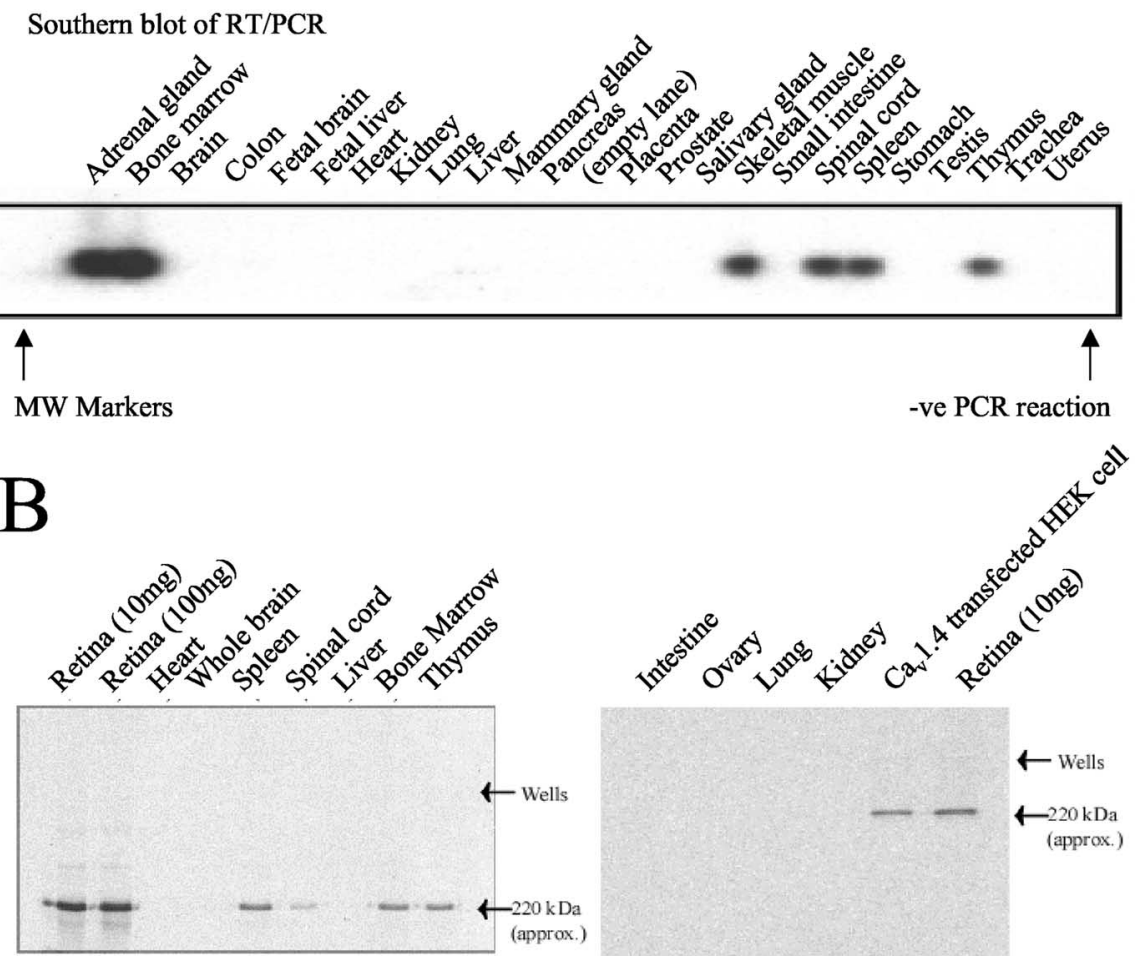

Figure 7. Tissue distribution of the $\mathrm{Ca}_{v} 1.4$ calcium channel in human and rat. $A, \mathrm{RT}-\mathrm{PCR}$ detected $\mathrm{Ca}_{\mathrm{v}} 1.4$ calcium channel transcripts in RNA from human adrenal gland, bone marrow, skeletal muscle, spinal cord, spleen, and thymus. One microgram of total human RNA was used in each RT-PCR reaction together with oligonucleotides specific to the $\mathrm{Ca}_{v} 1.4$ channel. PCR products were electrophoresed through a $1.8 \%$ agarose gel, blotted onto a nylon membrane, and probed with a [ $\left.\gamma^{-{ }^{32}} \mathrm{P}\right]$ ATP radiolabeled oligonucleotide specific to $C \mathrm{a}_{v} 1.4$. $B$, Western blot with $\mathrm{Ca}_{\mathrm{v}} 1.4$-specific antibody detects protein expression in rat retina, spleen, spinal cord, bone marrow, and thymus. Ten milligrams of total protein were separated through a 5\% SDS-PAGE acrylamide gel, blotted to nitrocellulose membrane, and then probed with the $\mathrm{Ca}_{\mathrm{v}} 1.4$-specific antibody. The results shown are representative of identical experiments using tissue from three separate rats.

that we report here, Koschak et al. (2003) also found that $\mathrm{Ca}_{\mathrm{v}} 1.4$ encodes for a novel type of DHP-sensitive calcium channel that lacks Ca-dependent inactivation; however, these authors did not use internal solutions with low calcium buffering capacity.

Photoreceptors tonically release glutamate in the dark because of sustained activity of L-type calcium channels (Taylor and Morgans, 1998). During a light stimulus, photoreceptors hyperpolarize, thus deactivating the L-type channels and terminating glutamate release. This necessitates that the L-type channels be tonically active at the typical photoreceptor resting potential of $-40 \mathrm{mV}$ (Schneeweis and Schapf, 1995). Like native rat and mouse bipolar cell L-type currents, transiently expressed $\mathrm{Ca}_{\mathrm{v}} 1.4$ channels bathed in $2 \mathrm{~mm}$ external calcium first activated $\sim-40$ $\mathrm{mV}$, demonstrating that this channel can indeed function in the range of typical photoreceptor resting membrane potentials. The large window current, together with the ultraslow inactivation displayed by $\mathrm{Ca}_{\mathrm{v}} 1.4$ channels, make this channel ideally suited for maintaining tonic glutamate release in photoreceptors. The need for the capability of this channel to undergo prolonged openings may be underscored by the inability of calcium channel $\beta$ subunits and calcium ions to accelerate inactivation kinetics (Figs. 3, 4). The molecular basis of this unique property remains to be explored. It is interesting to note that the $\mathrm{Ca}_{\mathrm{v}} 1.4$ channel contains IQ and EF hand motifs in the C-terminal regions, which should, in principle, permit calcium-sensitive inactivation to occur (Peterson et al., 1999). Indeed, the original work of Corey et al.
(1984) suggests that when the buffering capacity of the internal recording solution is reduced, some calcium-dependent inactivation may become apparent, similar to what has been described for other highvoltage-activated calcium channels (Lee et al., 1999; Zuhlke et al., 1999; Liang et al., 2003). However, we were unable to detect any calcium-dependent inactivation in the present study. Hence, it is yet to be determined as to whether calmodulin, the mediator of calcium-dependent inactivation in other HVA calcium channels, is capable of interacting with the $\mathrm{Ca}_{\mathrm{v}} 1.4 \mathrm{C}$ terminus.

The calcium channel $\beta$ subunit binding region in the domain I-II linker region of all high-threshold calcium channels is also conserved in $\mathrm{Ca}_{\mathrm{v}} 1.4$. However, the I-II linker contains an additional 29 amino acids, and the remainder of the I-II linker sequence diverges considerably from that of other types of HVA calcium channels, both of which may affect $\beta$ subunit interaction. In addition, it has been proposed that the domain I-II linker may serve as a physical inactivation gate of the channel and that $\beta$ subunits regulate inactivation kinetics by regulating the mobility of this region (Stotz and Zamponi, 2001a,b). It is possible that the $\mathrm{Ca}_{\mathrm{v}} 1.4 \mathrm{I}-\mathrm{II}$ linker serves only poorly as an inactivation-gating particle to begin with, hence, rendering ancillary $\beta$ subunits ineffective in regulating this process. We also cannot rule out the possibility that the ultraslow inactivation kinetics are not caused by a classical hinged-lid inactivation mechanism but instead reflect slow (C-type like) inactivation, or possibly a combination thereof.

\section{Missense mutations implicated in night blindness}

Examination of the functional consequences of naturally existing mutations in clinically affected individuals often represents an informative way to study both ion channel structure-function and to help understand the underlying clinical pathophysiology. In our analyses of three missense mutations and a carboxyl truncation associated with the CACNA1F gene and CSNB2, we found that only the G369D change in domain IS6 affected channel biophysical properties (Table 1). That only one missense mutation resulted in changes to biophysical properties and that the other two missense mutations and the premature stop did not seem to alter the biophysical properties of the channel is somewhat surprising, although not without precedence. For example, in some hypokalaemic periodic paralysis mutations found in skeletal muscle L-type calcium channels, the biophysical properties of the channels are only mildly altered, yet the clinical phenotype is quite severe (Lerche et al., 1996). Additionally, the effects of mutations in $\mathrm{Ca}_{\mathrm{v}} 2.1 \mathrm{P} / \mathrm{Q}$-type channels implicated in familial hemiplegic migraine ranged from little, if any, change in channel properties to dramatic alterations of gating kinetics (Kraus et al., 1998, 2000; Wappl et al., 2002). In the case of the $\mathrm{Ca}_{\mathrm{v}} 1.4$ channel, it is possible that channel activity in intact photoreceptors is regulated very tightly and that even subtle barely detectable changes in 

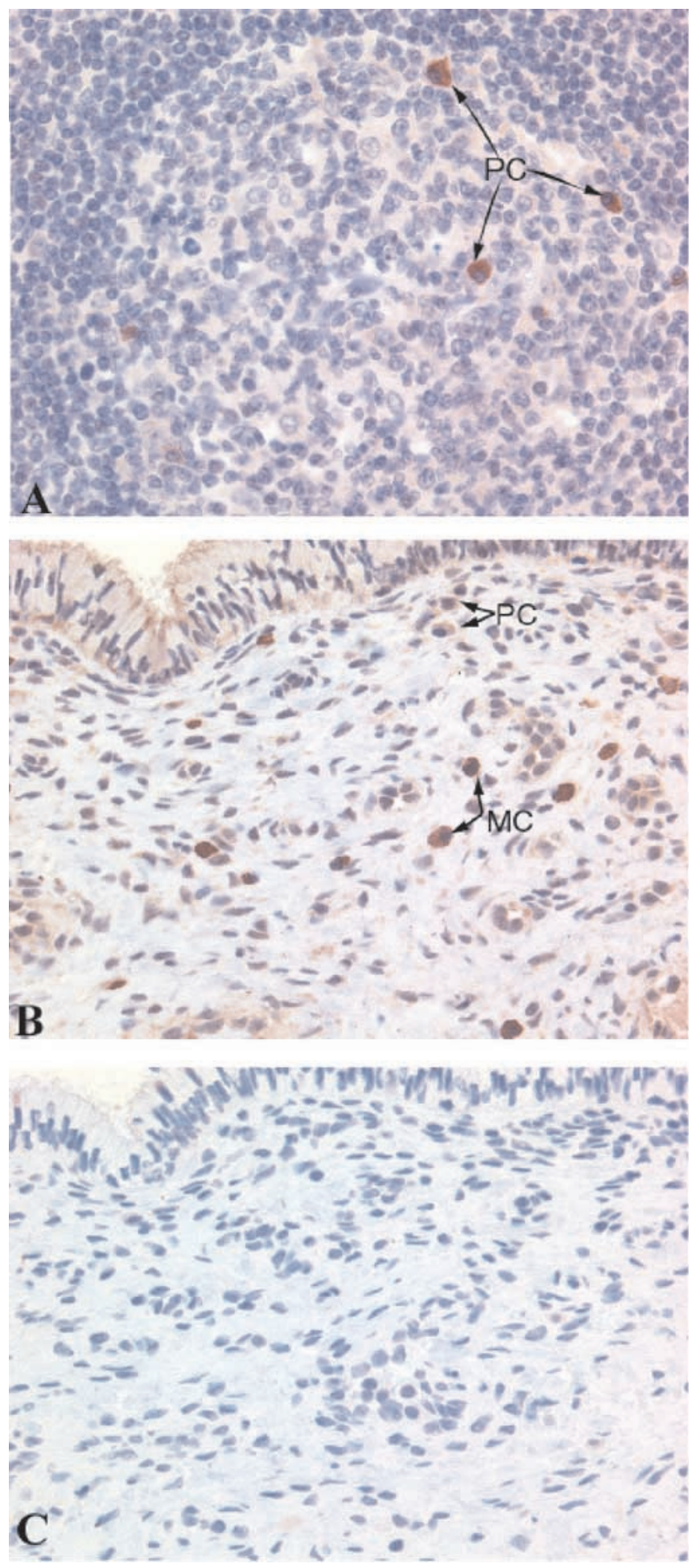

Figure 8. Ca $\quad \mathrm{a}_{\mathrm{v}} 1.4$ calcium channel expression in human lymphoid tissue. $A$, Tissue section of human lymph node immunostained with $\mathrm{Ca}_{v} 1.4$ antibody demonstrating immunoreactivity of plasma cells $(P C)$ in a germinal center. $B$, Tissue section of chronically inflamed human uterine cervix immunostained with $\mathrm{Ca}_{\mathrm{v}} 1.4$ antibody demonstrating immunoreactivity of $\mathrm{PC}$ as well as mast cells $(\mathrm{MC})$, in the cervical stroma. C, Section of cervix stained with $\mathrm{Ca}_{\mathrm{v}} 1.4$ antibody incubated with the blocking peptide (negative control). All images were captured at $400 \times$ magnification.

channel activity result in defective photoreceptor synaptic transmission. Alternatively, the effects of the mutations might not manifest themselves when the channel is removed from its native cellular environment. For example, it is conceivable that the mu- tations might interfere with the action of a regulatory protein that is present only in photoreceptors. Finally, in principle, it is also possible that some reported missense mutations might be polymorphisms found in the general population. Examination of additional mutations (Wutz et al., 2002) may reveal additional changes in $\mathrm{Ca}_{\mathrm{v}} 1.4$ channel function.

\section{Possible physiological function of $\mathrm{Ca}_{\mathrm{v}} 1.4$ outside of the retina}

Our data examining immunostaining in the human retina, together with the electrophysiological analysis, support a role of $\mathrm{Ca}_{\mathrm{v}} 1.4$ in rod photoreceptor synaptic transmission. $\mathrm{Ca}_{\mathrm{v}} 1.4$ was originally believed to be retinal specific (Bech-Hansen et al. 1998a,b; Strom et al., 1998); however, our data indicate that this is unlikely to be the case. $\mathrm{Ca}_{\mathrm{v}} 1.4 \mathrm{mRNA}$ and protein were both detected in bone marrow, thymus, adrenal gland, and skeletal muscle. Interestingly, the slow inactivation kinetics of $\mathrm{Ca}_{\mathrm{v}} 1.4$ would make this channel an ideal candidate for supporting hormone secretion, similar to what has been suggested for $\mathrm{Ca}_{\mathrm{v}} 1.3$ channels in insulin-secreting cells, and the presence of $\mathrm{Ca}_{\mathrm{v}} 1.4$ in the adrenal gland and thymus may be consistent with such a role. It is more difficult to ascribe a functional role of $\mathrm{Ca}_{\mathrm{v}} 1.4$ in skeletal muscle and spinal cord, and future experiments examining more carefully the distribution of these channels in these tissues will be required.

Immunohistochemical staining of lymph tissue and cervical stroma displayed a strong cross-reactivity to the $\mathrm{Ca}_{\mathrm{v}} 1.4$ antibody. Of particular note, the activation and release of both plasma cells and mast cell contents is regulated by the influx of calcium, although the mechanism by which this occurs is presently unknown (Rohlich et al., 1971; Sollner et al., 1993; Kim et al., 1997). Our data suggest the possibility that one means by which calcium enters plasma and mast cells is through the $\mathrm{Ca}_{\mathrm{v}} 1.4 \mathrm{~L}$-type calcium channel. Previous reports have suggested that L-type calcium channels function on the surface of plasma and mast cells as treatment with the L-type calcium channel blocker nifedipine suppresses calcium transport into these cells (Briede et al., 1999). In addition, the presence of syntaxin peptides and synaptotagmin in mast cells suggest a support/scaffold role for L-type calcium channel-mediated exocytosis (Baram et al., 1998, 2001; Pombo et al., 2001). Interestingly, calcium-dependent exocytosis in mast cells is stimulated by the calcium sensor synaptotagmin I, whereas syntaptotagmin II negatively regulates MHC class II presentation by mast cells (Baram et al., 1999, 2002). In addition, in a rat basophilic leukemia cell (RBL-2H3), expression of the calcium sensor synaptotagmin has been shown to initiate the targeting of the secretory granules near the cell membrane. It would be interesting in future studies to examine whether synaptotagmin I and II regulate $\mathrm{Ca}_{\mathrm{v}} 1.4$ function and whether the $\mathrm{Ca}_{\mathrm{v}} 1.4$ channel colocalizes with either of the synaptotagmins within mast and plasma cells.

\section{References}

Akopian A, Johnson J, Gabriel R, Brecha N, Witkovsky P (2000) Somatostatin modulates voltage-gated $\mathrm{K}^{+}$and $\mathrm{Ca}^{2+}$ currents in rod and cone photoreceptors of the salamander retina. J Neurosci 20:929-936.

Ball SL, Powers PA, Shin HS, Morgans CW, Peachey NS, Gregg RG (2002) Role of the beta(2) subunit of voltage-dependent calcium channels in the retinal outer plexiform layer. Invest Ophthalmol Vis Sci 43:1595-1603.

Baram D, Linial M, Mekori YA, Sagi-Eisenberg R (1998) $\mathrm{Ca}^{2+}$-dependent exocytosis in mast cells is stimulated by the $\mathrm{Ca}^{2+}$ sensor, synaptotagmin I. J Immunol 161:5120-5123.

Baram D, Adachi R, Medalia O, Tuvim M, Dickey BF, Mekori YA, SagiEisenberg R (1999) Synaptotagmin II negatively regulates $\mathrm{Ca}^{2+}$ triggered exocytosis of lysosomes in mast cells. J Exp Med 189:1649-1658. 
Baram D, Mekori YA, Sagi-Eisenberg R (2001) Synaptotagmin regulates mast cell functions. Immunol Rev 179:25-34.

Baram D, Peng Z, Medalia O, Mekori Y, Sagi-Eisenberg R (2002) Synaptotagmin II negatively regulates MHC class II presentation by mast cells. Mol Immunol 38:1347-1352.

Barnes S (1994) After transduction: response shaping and control of transmission by ion channels of the photoreceptor inner segments. Neuroscience 58:447-459.

Barnes S, Hille B (1989) Ionic channels of the inner segment of tiger salamander cone photoreceptors. J Gen Physiol 94:719-743.

Barnes S, Kelly M (2004) Voltage-gated Ca channels of the vertebrate retina: from the genetics of blindness to encoding the visual world. In: Voltagegated calcium channels (Zamponi G, ed), Landes Bioscience, in press.

Beam KG, Adams BA, Niidome T, Numa S, Tanabe T (1992) Function of a truncated dihydropyridine receptor as both voltage sensor and calcium channel. Nature 360:169-171.

Bech-Hansen NT, Boycott KM, Gratton KJ, Ross DA, Field LL, Pearce WG (1998a) Localization of a gene for incomplete X-linked congenital stationary night blindness to the interval between DXS6849 and DXS8023 in Xp11.23. Hum Genet 103:124-130.

Bech-Hansen NT, Naylor MJ, Maybaum TA, Pearce WG, Koop B, Fishman GA, Mets M, Musarella MA, Boycott KM (1998b) Loss-of-function mutations in a calcium-channel alphal-subunit gene in Xp11.23 cause incomplete X-linked congenital stationary night blindness. Nat Genet 19:264-267.

Berntson A, Taylor WR, Morgans CW (2003) Molecular identity, synaptic localization, and physiology of calcium channels in retinal bipolar cells. J Neurosci Res 71:146-151.

Boycott KM, Pearce WG, Bech-Hansen NT (2000) Clinical variability among patients with incomplete X-linked congenital stationary night blindness and a founder mutation in CACNA1F. Can J Opthalmol 35:204-213.

Briede J, Daija D, Bisenieks E, Makarova N, Uldrikis J, Poikans J, Duburs G (1999) Effects of some 1,4-dihydropyridine Ca antagonists on the blast transformation of rat spleen lymphocytes. Cell Biochem Funct 17:97-105.

Corey DP, Dubinsky JM, Schwartz EA (1984) The calcium current in inner segments of rods from the salamander (Ambystoma tigrinum) retina. J Physiol (Lond) 354:557-575.

de la Villa P, Vaqueor CF, Kaneko A (1998) Two types of calcium currents of the mouse bipolar cells recorded in the retinal slice preparation. Eur J Neurosci 10:317-323.

DeMaria CD, Soong TW, Alseikham BA, Alvania RS, Yue DT (2001) Calmodulin bifurcates the local $\mathrm{Ca}^{2+}$ signal that modulates P/Q-type calcium channels. Nature 411:484-489.

Hell JW, Westenbroek RE, Warner C, Ahlijanian MK, Prystay W, Gilbert MM, Snutch TP, Catterall WA (1993) Identification and differential subcellular localization of the neuronal class $C$ and class D L-type calcium channel alpha 1 subunits. J Cell Biol 123:949-962.

Kim TD, Eddlestone GT, Mahmoud SF, Kuchtey J, Fewtrell C (1997) Correlating $\mathrm{Ca}^{2+}$ responses and secretion in individual RBL-2H3 mucosal mast cells. J Biol Chem 272:31225-31229.

Knapp AP, Dowling JE (1987) Dopamine enhances excitatory amino acidgated conductances in cultured retinal horizontal cells. Nature 325:437-439.

Koschak A, Reimer D, Huber I, Grabner M, Glossmann H, Engel J, Striessnig J (2001) Alpha 1D $\left(\mathrm{Ca}_{\mathrm{v}} 1.3\right)$ subunits can form L-type $\mathrm{Ca}^{2+}$ channels activating at negative voltages. J Biol Chem 276:22100-22106.

Koschak A, Reimer D, Walter D, Hoda J-C, Heinzle T, Grabner M, Striessnig J (2003) $\mathrm{Ca}_{\mathrm{v}} 1.4 \quad \alpha 1$ subunits can form slowly inactivating dihydropyridine-sensitive L-type $\mathrm{Ca}^{2+}$ channels lacking $\mathrm{Ca}^{2+}$ - sensitive inactivation. J Neurosci 23:6041-6049.

Kourennyi DE, Barnes S (2000) Depolarization-induced calcium channel facilitation in rod photoreceptors is independent of $\mathrm{G}$ proteins and phosphorylation. J Neurophysiol 84:133-138.

Kraus RL, Sinnegger MJ, Glossmann H, Hering S, Striessnig J (1998) Familial hemiplegic migraine mutations change alpha1 $\mathrm{A} \mathrm{Ca}^{2+}$ channel kinetics. J Biol Chem 273:5586-5590.

Kraus RL, Sinnegger MJ, Koschak A, Glossmann H, Stenirri S, Carrera P, Striessnig J (2000) Three new familial hemiplegic migraine mutants affect P/Q-type $\mathrm{Ca}^{2+}$ channel kinetics. J Biol Chem 275:9239-9243.

Kurenny DE, Moroz LL, Turner RW, Sharkey KA, Barnes S (1994) Modu- lation of ion channels in rod photoreceptors by nitric oxide. Neuron 13:315-324.

Lee A, Wong ST, Gallagher D, Li B, Storm DR, Scheuer T, Catterall WA (1999) $\mathrm{Ca}^{2+} /$ calmodulin binds to and modulates $\mathrm{P} / \mathrm{Q}$-type calcium channels. Nature 399:155-159.

Lerche H, Klugbauer N, Lehmann-Horn F, Hofmann F, Melzer W (1996) Expression and functional characterization of the cardiac L-type calcium channel carrying a skeletal muscle DHP-receptor mutation causing hypokalaemic periodic paralysis. Pflugers Arch 431:461-463.

Liang H, DeMaria CD, Erickson MG, Mori MX, Alseikhan BA, Yue DT (2003) Unified mechanisms of $\mathrm{Ca}^{2+}$ regulation across the $\mathrm{Ca}^{2+}$ channel family. Neuron 39:951-960.

Matthews HR (1995) Effects of lowered cytoplasmic calcium concentration and light on the responses of salamander rod photoreceptors. J Physiol (Lond) 484:267-286.

Morgans CW (1999) Calcium channel heterogeneity among cone photoreceptors in the tree shrew retina. Eur J Neurosci 11:2989-2993.

Morgans CW (2001) Localization of the alpha1F calcium channel subunit in the rat retina. Invest Ophthalmol Vis Sci 42:2414-2418.

Morgans CW, Gaughwin P, Maleszka R (2001) Expression of the alpha1F calcium channel subunit by photoreceptors in the rat retina. Mol Vis 7:202-209.

Nachman-Clewner M, Jules RST, Townes-Anderson E (1999) L-type calcium channels in the photoreceptor ribbon synapse: localization and role in plasticity. J Comp Neurol 415:1-16.

Olcese R, Qin N, Schneider T, Neely A, Wei X, Stefani E, Birnbaumer L (1994) The amino terminus of a calcium channel beta subunit sets rates of channel inactivation independently of the subunit's effect on activation. Neuron 13:1433-1438.

Peterson BZ, DeMaria CD, Adelman JP, Yue DT (1999) Calmodulin is the $\mathrm{Ca}^{2+}$ sensor for $\mathrm{Ca}^{2+}$-dependent inactivation of L-type calcium channels. Neuron 22:549-558.

Pombo I. Martin-Verdeaux S, Iannascoli B, Le Mao J, Deriano L, Rivera J, Blank U (2001) IgE receptor type I-dependent regulation of a Rab3Dassociated kinase: a possible link in the calcium-dependent assembly of SNARE complexes. J Biol Chem 276:42893-42900.

Protti D, Llano I (1998) Calcium currents and calcium signaling in rod bipolar cells of rat retinal slices. J Neurosci 18:3715-3724.

Puro DG, Hwang JJ, Kwon OJ, Chin H (1996) Characterization of an L-type calcium channel expressed by human Muller (glial) cells. Brain Res Mol Brain Res 37:41-48.

Rohlich P, Anderson P, Uvnas B (1971) Electron microscope observations on compounds 48-80-induced degranulation in rat mast cells. Evidence for sequential exocytosis of storage granules. J Cell Biol 51:465-483.

Schneeweis DM, Schnapf JL (1995) Photovoltage of rods and cones in the macaque retina. Science 268:1053-1056.

Seino S, Chen L, Seino M, Blondel O, Takeda J, Johnson JH, Bell GI (1992) Cloning of the $\alpha 1$ subunit of a voltage-dependent calcium channel expressed in pancreatic $\beta$ cells. Proc Natl Acad Sci USA 89:584-588.

Sollner T, Whiteheart SW, Brunner M, Erdjument-Bromage H, Geromanos S, Tempst P, Rothman JE (1993) SNAP receptors implicated in vesicle targeting and fusion. Nature 362:318-324.

Stotz SC, Hamid J, Spaetgens RL, Jarvis SE, Zamponi GW (2000) Fast inactivation of voltage-dependent calcium channels. A hinged-lid mechanism? J Biol Chem 275:24575-24582.

Stotz SC, Zamponi GW (2001a) Identification of inactivation determinants in the domain IIS6 region of high voltage-activated calcium channels. J Biol Chem 276:33001-33010.

Stotz SC, Zamponi GW (2001b) Structural determinants of fast inactivation of high voltage-activated $\mathrm{Ca}^{2+}$ channels. Trends Neurosci 24:176-181.

Strom TM, Nyakatura G, Apfelstedt-Sylla E, Hellebrand H, Lorenz B, Weber BH, Wutz K, Gutwillinger N, Ruther K, Drescher B, Sauer C, Zrenner E, Meitinger T, Rosenthal A, Meindl A (1998) An L-type calcium-channel gene mutated in incomplete $\mathrm{X}$-linked congenital stationary night blindness. Nat Genet 19:260-263.

Taylor WR, Morgans C (1998) Localization and properties of voltage-gated calcium channels in cone photoreceptors of Tupaia belangeri. Vis Neurosci 15:541-552.

Thoreson WB, Stella SL (2000) Anion modulation of calcium current voltage dependence and amplitude in salamander rods. Biochem Biophys Acta 1464:142-150. 
Thoreson WB, Gottesman J, Jane DE, Tse HW, Watkins JC, Miller RF (1997) Two phenylglycine derivatives antagonize responses to L-AP4 in ON bipolar cells of the amphibian retina. Neuropharmacology 36:13-20.

Wappl E, Koschak A, Poteser M, Sinnegger MJ, Walter D, Eberhart A, Groschner K, Glossmann H, Kraus RL, Grabner M, Striessnig J (2002) Functional consequences of P/Q-type $\mathrm{Ca}^{2+}$ channel $\mathrm{Ca}_{\mathrm{v}} 2.1$ missense mutations associated with episodic ataxia type 2 and progressive ataxia. J Biol Chem 277:6960-6966.

Wheeler DB, Randall A, Tsien RW (1994) Roles of N-type and Q-type Ca ${ }^{2+}$ channels in supporting hippocampal synaptic transmission. Science 264:107-111.

Wilkinson MF, Barnes S (1996) The dihydropyridine-sensitive calcium channel subtype in cone photoreceptors. J Gen Physiol 107:621-630.

Williams ME, Feldman DH, McCue AF, Brenner R, Velicelebi G. Ellis SB, Harpold MM (1992a) Structure and functional expression of alpha 1, alpha 2, and beta subunits of a novel human neuronal calcium channel subtype. Neuron 8:71-84.

Williams ME, Brust PF, Feldman DH, Patthi S, Simerson S, Maroufi A, Mc-
Cue AF, Velicelebi G, Ellis SB, Harpold MM (1992b) Structure and functional expression of an omega-conotoxin-sensitive human N-type calcium channel. Science 257:389-395.

Wutz K, Sauer C, Zrenner E, Lorenz B, Alitalo T, Broghammer M, Hergersberg M, de la Chapelle A, Weber BH, Wissinger B, Meindl A, Pusch CM (2002) Thirty distinct CACNA1F mutations in 33 families with incomplete type of XLCSNB and CACNA1F expression profiling in mouse retina. Eur J Hum Genet 8:449-546.

$\mathrm{Xu}$ W, Lipscombe D (2001) Neuronal $\mathrm{Ca}_{\mathrm{v}} 1.3$ alpha $_{1}$ L-type channels activate at relatively hyperpolarized membrane potentials and are incompletely inhibited by dihydropyridines. J Neurosci 21:5944-5951.

Xu HP, Zhao JW, Yang XL (2002) Expression of voltage-dependent calcium channel subunits in the rat retina. Neurosci Lett 329:297-300.

Yagi T, Macleish PR (1994) Ionic conductances of monkey solitary cone inner segments. J Neurophysiol 71:656-665.

Zuhlke RD, Pitt GS, Deisseroth K, Tsien RW, Reuter H (1999) Calmodulin supports both inactivation and facilitation of L-type calcium channels. Nature 399:159-162. 